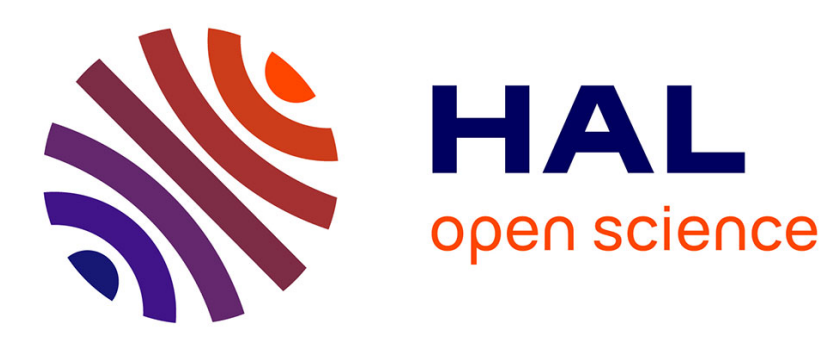

\title{
Mechanical decoupling of high-pressure crustal units during continental subduction.
}

Nicolas Carry, F. Gueydan, Didier Marquer, Jean-Pierre Brun

\section{To cite this version:}

Nicolas Carry, F. Gueydan, Didier Marquer, Jean-Pierre Brun. Mechanical decoupling of high-pressure crustal units during continental subduction.. Earth and Planetary Science Letters, 2009, 278 (1-2), pp.13-25. 10.1016/j.epsl.2008.11.019 . hal-00371066

\section{HAL Id: hal-00371066 https://hal.science/hal-00371066}

Submitted on 26 Mar 2009

HAL is a multi-disciplinary open access archive for the deposit and dissemination of scientific research documents, whether they are published or not. The documents may come from teaching and research institutions in France or abroad, or from public or private research centers.
L'archive ouverte pluridisciplinaire HAL, est destinée au dépôt et à la diffusion de documents scientifiques de niveau recherche, publiés ou non, émanant des établissements d'enseignement et de recherche français ou étrangers, des laboratoires publics ou privés. 


\title{
Mechanical decoupling of high-pressure crustal units during continental subduction.
}

\author{
N. Carry ${ }^{1}$, F. Gueydan $2^{*}$, J.P. Brun², D. Marquer ${ }^{1}$ \\ Carry, N., Gueydan, F., Brun, J. P., and Marquer, D. (2009) Mechanical decoupling of high-pressure crustal units \\ during continental subduction, Earth and Planetary Science Letters 278, 13-25. \\ ${ }^{1}$ Chrono-Environnement UMR 6249, Universite de Franche-Comte \\ 16 route de Gray, 25030 Besancon, France \\ ${ }^{2}$ Geosciences Rennes UMR6118, Universite de Rennes 1 \\ Campus de Beaulieu CS 74205, 35042 Rennes cedex, France \\ * Corresponding author: frederic.gueydan@univ-rennes1.fr
}

\begin{abstract}
The mechanics of the transition from continental subduction toward upper crustal nappe stacking is still poorly understood and is studied here through a $2 \mathrm{D}$ thermal and strength numerical modelling of a subducted passive margin. Geological observations in the core of most mountain belts show the piling up of several HP-LT upper crustal units that are most likely related to the detachment of upper crustal units from the subducted continental margin and to the subsequent stacking of the detached units at depths. The Adula unit (Lepontine dome, Central Alps, Switzerland) is a long and thin upper crustal unit and is used here as a natural case-study as it provides a well-documented example of these units. 2D thermal modeling shows that two steps, successive in time, characterized the burial history of the passive margin undergoing continental subduction: 1-an increase in the margin strength due to an increase in the confining pressure during the first million years of the margin subduction and 2-the progressive heating of the subducted margin from the overlying lithosphere leads to a decrease in the margin strength due to thermal weakening, which progressively counter-balances the increase in confining pressure. Two strength gradients develop within the subducted lithosphere: 1-along the slab, the strength decreases with increasing burial depth and 2-perpendicular to the slab, the strength increases with depth due to an inverse temperature distribution. The detachment of HP-LT continental units from the subducted margin could occur when the slab strength becomes lower than the applied net stress. This allows the detachment of ductile weakened thin and long upper-crustal units. The thickness and length of the detached crustal units are controlled by the following parameters, in order of their importance: subduction dip angle, crustal rheology, mantle heat flux and subduction velocity. The comparison of our model results with the geometry and PT conditions of the Adula unit yields an estimate of the Alpine subduction dip angle at the time of deformation and metamorphism.
\end{abstract}

keywords: numerical modeling - lithosphere strength - HP-LT metamorphism 


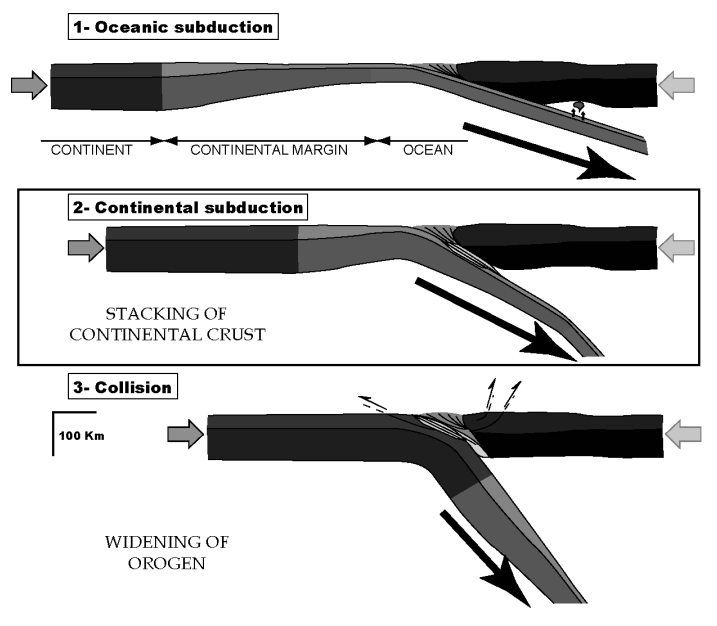

Figure 1: Schematic drawing of a three-step evolution in a convergence zone at a lithosphere scale. 1-Oceanic subduction, 2-Continental subduction, 3-Collision. This study focused on the continental subduction and subsequent detachment of the HP-LT crustal unit, as indicated by the black box.

\section{Introduction}

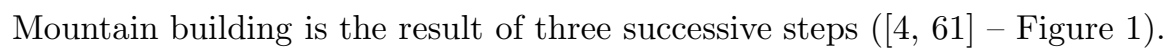

The first stage is oceanic subduction, which induces the formation of oceanic accretionary wedges. Second, the subduction of continental margin induces the stacking of long and thin upper crustal units at great depths [10, 24, 43], and leads to the piling-up of high-pressure, low-temperature (HP-LT) units. At this stage, the convergence between the two plates is mostly accommodated within the subduction zone, where the stacking of HP-LT metamorphic units occurs [31, 29, 35]. Third, the ongoing convergence induces a more penetrative shortening, which leads to a pronounced thickening on a lithosphere scale. This induces the widening of the orogen, marked by the migration of orogenic fronts 40, 4] and defines the collision sensu-stricto (Figure 1 1 - 3 ). These three stages are well defined in the Alps, and therefore, we have chosen this will area as our field case-study in this paper. Oceanic closure and the beginning of oceanic subduction in the Liguro-Piemontais Ocean started during Cretaceous time (Albo-aptien, $100 \mathrm{Ma}$ 49, 62, 18, 57). The age of the continental subduction is established by HP-LT and UHP metamorphism ages, which range from the Eocene to the Early Oligocene (50-35 Ma - 62, 14, 6, 19, 27, 57, 61, 44). Finally, continental collision sensu-stricto occurred during the late Oligocene and the Miocene (30-15 Ma) as evidenced by the ages of the successive frontal thrust in the northern ans southern parts of the Alpine collision belt [9, 37, 15, 16].

Most of the numerical models of orogenic processes analyze the evolution from subduction to collision on a lithosphere scale, with an emphasis on exhumation processes and surface-tectonic interactions «, 21, 22]. The three successive steps of orogenic formation have been modeled with a particular focus on the role of crustal rheology (a weak upper crust versus a strong lower crust) and the crust-mantle coupling in defining the crustal thickening style. In these types of models, the depths at which the upper crustal material is detached from the down going subducted plate is indirectly imposed by a velocity discontinuity (called point $\mathrm{S}$, [4, 21, 54, 8]). This velocity discontinuity is often defined at the crust-mantle boundary and avoids detachment of continental unit at depths greater than $60 \mathrm{~km}$ [5, 4, 21, 54]. The aim of the present paper is to analyze the processes that control the detachment of a crustal unit during continental subduction. This topic is crucial to quantify the parameters that control the maximum depth reached by a crustal unit in a continental subduction and subsequently to better understand the parameters that define the peak pressure of metamorphic rocks. This topic is also a first step toward understanding the piling-up of HP-LT units, which is typical of the core of mountain belts.

Van den Beukel [5] was the first to attempt to describe stacking during the subduction of a continental margin. Assuming a relatively hot subduction thermal gradient, Van den Beukel [5] qualitatively discussed the conditions for stacking occurrence by comparing the margin strength, inferred from the 2D thermal states of continental subduction, and the applied net stress. The margin strength is shown to increase during the first $20-40 \mathrm{~km}$ of the burial history and then decreases at greater burial depths. The applied net stress along the subduction plate, which was assumed to be the sum of the buoyancy plus the resisting stress, increases with burial depth. At burial depths greater than 30-40 km, the margin strength becomes lower than the applied net stress, leading to a possible thrust sheet detachment. However, the detachment is dictated by a prescribed rheological discontinuity at the 


\begin{tabular}{|c|c|c|c|c|c|}
\hline & $\begin{array}{c}\text { Density } \\
\rho\left(\mathrm{kg} . \mathrm{m}^{-3}\right)\end{array}$ & $\begin{array}{c}\text { Capacity } \\
\left(\mathrm{J} . \mathrm{kg}^{-1} \cdot \mathrm{K}^{-1}\right)\end{array}$ & $\begin{array}{c}\text { Thermal conductivity } \\
\left(\mathrm{W} \cdot \mathrm{m}^{-1} \cdot \mathrm{K}^{-1}\right)\end{array}$ & $\begin{array}{c}\text { Radiogenic heat } \\
\left(\mu \mathrm{W} \cdot \mathrm{m}^{-3}\right)\end{array}$ & $\begin{array}{c}\text { Thickness } \\
(\mathrm{km})\end{array}$ \\
\hline Upper crust & 2800 & 1000 & 2,1 & 1,0 & 10 to 3 \\
Lower crust & 2800 & 1000 & 2,1 & 0,0 & 30 to 10 \\
Mantle & 3300 & 1000 & 3,0 & 0,0 & 70 to 90 \\
\hline
\end{tabular}

Table 1: Thermal parameters for the 2D thermal models from Turcotte and Schubert 64. The thickness of the radiogenic crust (upper crust) is set to one-third of the crust thickness.

base of the weak upper crust. The depth at which stacking occurs is seen to decrease with an increasing subduction thermal gradient and increases with increasing convergence velocity. Therefore, thermal heating, and hence strength weakening, during continental subduction seems to control unit stacking at depths. The role of subduction velocity, subduction dip angle and crustal rheology in defining the stacking depth need to be more systematically investigated. Moreover, the relationship between continental unit thickness/length and stacking processes remains poorly constrained. These are the two main objectives of the present paper.

Using a 2D thermal and strength model of the continental subduction, we will show that thin crustal units could detach from the subducted lithosphere due to a thermal weakening of the continental margin during burial and without prescribed rheological heterogeneities. The comparison of the applied net stress along the subduction plane and the 2D margin strength allows us to quantitatively predict stacking areas (e.g. unit length and thickness) within the margin crust. The role of subduction dip angle, subduction velocity, rheological and thermal parameters are investigated. Finally, our model predictions are tentatively compared with the Adula unit (Lepontine dome, Swiss Alps).

\section{Model}

Following Van den Beukel [0], this study is based on a 2D comparison of the applied net stress along the subduction plane and of the margin strength that evolves with burial history. The applied net stress is estimated by a simple force balance analysis, that is slightly different to that proposed by Van den Beukel. The margin strength is calculated from the 2D temperature distribution within the subducted lithosphere, which evolves with burial history (Figure 2).

\section{$2.12 \mathrm{D}$ thermal modeling}

The 2D transient heat conduction is solved using the finite element method and the numerical code SARPP (see detailed description in Gueydan et al. [28] and Leroy et al. [38]):

$$
\rho . C \cdot \frac{\partial T}{\partial t}-k \cdot\left(\frac{\partial^{2} T}{\partial x^{2}}+\frac{\partial^{2} T}{\partial y^{2}}\right)=r
$$

where $\rho, C, k$ and $r$ are the density, capacity, thermal conductivity and radiogenic heat production, respectively. The values of these parameters for the crust and the lithosphere mantle are given in Table 1. The heat equation is solved only in the subducted lithosphere and in the thin low-conductive overlying layer (Figure 2-ab). The 2D temperature distribution within the overlying lithosphere is assumed to be a steady-state continental geotherm defined by the mantle heat flux, crustal thickness and radiogenic heat production within a $10 \mathrm{~km}$ thick radiogenic crust. The value of the heat flux will be changed in this study. The presence of a thin and low conductive overlying layer on the top of the subducted lithosphere accounts for the heat transport between the subducted lithosphere and the overlying lithosphere (Figure 2-b). The thickness of that layer has been set to $3 \mathrm{~km}$ and its conductivity varies between 1.0 to $2.0 \mathrm{~W} \cdot \mathrm{m}^{-1} \cdot \mathrm{K}^{-1}$ and has been adjusted so that our 2D modeled temperature distribution within the subducted lithosphere is comparable to that of previous $2 \mathrm{D}$ models. At a conductivity $k_{s}$ of $1.75 \mathrm{~W} \cdot \mathrm{m}^{-1} \cdot \mathrm{K}^{-1}$, Appendix A provides a detailed comparison between our modelling and previous studies and shows no major differences in terms of temperature estimates for varying subduction dip angle and velocity.

The temperature boundary conditions for the subducted lithosphere are as follows. A mantle heat flux is applied at the base of the structure while a temperature that evolves with time (e.g. during burial) is applied at the top of the overlying layer. At a given time and for a given horizontal position in the subducted plate, the top temperature is that given by the steady-state geotherm of the overlying lithosphere plate (Figure 2a and 2ac). The top temperature therefore increases with time (e.g. with burial) and that increase is faster for both larger 

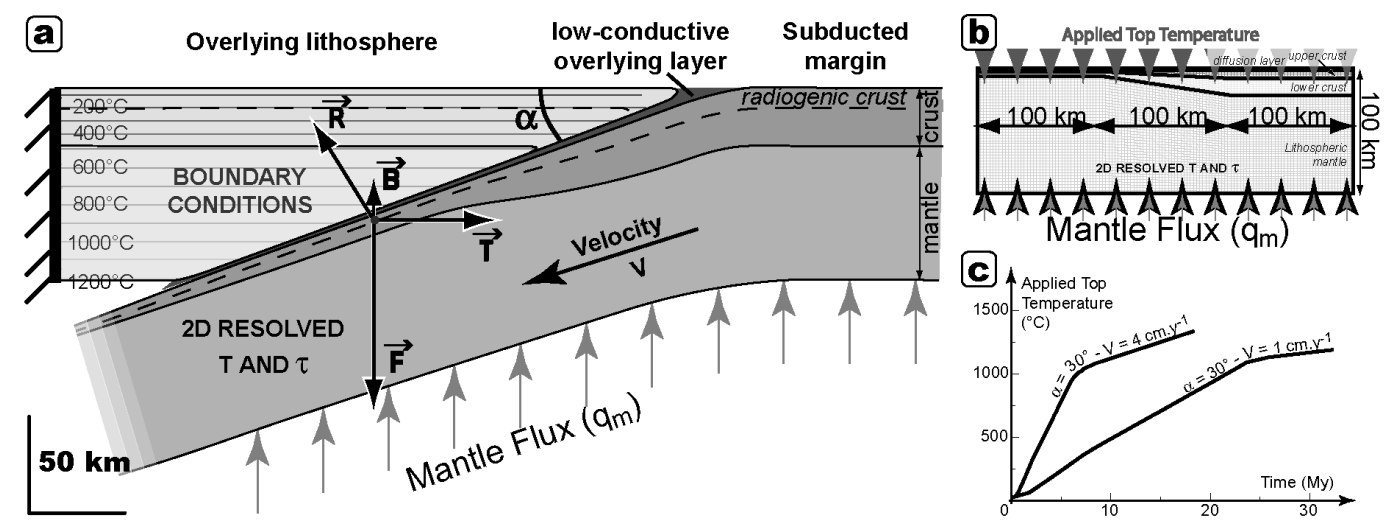

Figure 2: Model set-up. a-2D thermal model and the three forces acting on the subducted continental margin: buoyancy $\vec{B}$, tectonic $\vec{T}$ and overlying weight $\vec{F}$ forces. At equilibrium, the acting force i.e. the sum of the three previous forces, is equal to the opposite of the reaction material force: $\vec{A}=-\vec{R}$. See Appendix B for a detailed description of the forces and related stresses. Continental subduction is described by a dip angle $\alpha$ and velocity $V$. Thermal boundary conditions are a steady-state continental geotherm in the overlying lithosphere and a mantle heat flux $q_{m}$ at the base of the subducted lithosphere. The $2 \mathrm{D}$ model will resolve heat conduction only in the subducted lithosphere and a thin low-conductive overlying layer, which accounts for heat transport between the subducted lithosphere and the overlying lithosphere. The subducted lithosphere strength will be also calculated from the $2 \mathrm{D}$ temperature distribution, which evolves with the burial history. b-The geometry of the passive margin that will enter subduction is composed by three successive $100 \mathrm{~km}$ long domains: a thinned lithosphere with a $10 \mathrm{~km}$ thick crust, a transition zone where the crustal thickness progressively increases and finally, a nonthinned lithosphere with a $30 \mathrm{~km}$ thick continental crust. c-The applied top temperature calcuated from the steady continental geotherm of the overlying lithosphere increases with burial depths, and thus time, as a function of the subduction dip angle $(\alpha)$ and the velocity $(V)$. See text for further details.

subduction velocities and subduction dip angles (Figure 2 2 c). We systematically investigated the role of these two parameters in defining the $2 \mathrm{D}$ temperature and strength distribution within the subducted margin.

The initial condition includes the 2D temperature distribution of a passive margin with an age of $120 \mathrm{My}$ after break-up, defined by the previous modeling done by Leroy et al. 38]. At that age, the thermal equilibrium is almost reached and thus, the lithosphere-asthenosphere boundary is nearly flat [38]. Following (author?) 38, the geometry of the passive-margin that will enter subduction is composed of three successive $100 \mathrm{~km}$ long domains: a thinned lithosphere with a $10 \mathrm{~km}$ thick crust, a transition zone where the crustal thickness progressively increases and finally, a non-thinned lithosphere with a $30 \mathrm{~km}$ thick continental crust (Figure 2 $\mathrm{b}$ ). The studied structure has been divided into $60 \times 30$ lagrangian elements. This geometry is typical of a non-volcanic passive margin [48, 25, 3, 38]. In the present paper, we will not discuss the role of that geometry in the stacking process; instead we prefer to study the role of thermal and rheological parameters in details.

Shear heating and advection have been neglected in the present study. England and Wilkins [20] have recently exemplified the role of frictional heating and heat dissipation on the thermal state of the oceanic slab during oceanic subduction. In a continental subduction environment, the physics of such frictional heating is however less constrained and even undefined, for varying subduction dip angles and subduction velocities [51, 11]. A fully coupled thermo-mechanical analysis would permit to have a $2 \mathrm{D}$ strain rate pattern within the subducted plate and subsequently, an accurate modeling of either the shear or frictional heating [51, 32, 33, 11]. In the present paper, we prefer to use a simple numerical model in order to focus on the role of thermal and rheological parameters in the stacking process at deep burial depths. Therefore, the thermo-mechanical analysis and thus, the role of either shear or frictional heating, is beyond the scope of this paper and will be post-poned to future works.

\section{$2.2 \quad$ Strength estimate}

The strength of the subducted margin is calculated from the $2 \mathrm{D}$ temperature distribution as follows. The material strength is defined as the minimum brittle strength $\left(\tau_{b}\right)$ and ductile strength $\left(\tau_{d}\right)$. The brittle strength $\left(\tau_{b}\right)$ is the Mohr-Coulomb shear stress, which increases with lithostatic pressure and therefore, with burial depth:

$$
\tau_{b}=\sigma_{1}-\sigma_{3}=2 . \mu^{\star} . P=\frac{2 . \mu . \rho . g . z}{\sqrt{\mu^{2}+1} \pm \mu}
$$




\begin{tabular}{|l|c|c|c|c|}
\hline Rheology & $A\left({\mathrm{MPa} . \mathrm{s}^{-1}}\right)$ & $Q\left(\mathrm{kJ.mol}^{-1}\right)$ & $n$ & Reference \\
\hline Dry Plagioclase (crust) & $3,2.10^{-4}$ & 238,0 & 3,2 & Ranalli 2003 [56] \\
Wet Quartz (crust) & $4.0 .10^{-4}$ & 152,0 & 2,5 & Paterson 1990 [50] \\
Mafic Granulite (crust) & $1,4.10^{+4}$ & 445 & 4,2 & Wilks 1990 [65] \\
Dry Olivine (mantle) & $2,4.10^{-5}$ & 540,0 & 3,5 & Karato 1993 [36] \\
\hline
\end{tabular}

Table 2: Ductile rheological parameters used to compute the ductile strength from the 2D temperature distribution within the subducted continental lithosphere.

where $\mu$ is the friction coefficient, $\rho$ is the density of rocks above depth $z$, and $g$ is the acceleration of gravity. The depth $z$ is the burial depth increasing with time plus the vertical position within the subducted margin. The sign $( \pm \mu)$ before the coefficient of friction depends on the tectonic regime: it is positive in a compression mode and negative in an extension mode. Therefore, the parameter $\mu^{\star}$ is an apparent friction coefficient that accounts for the tectonic setting and for pore fluid pressure effect [55. For our study, $\mu^{\star}$ is equal to 2.12 in compression, with a friction coefficient of 0.7 [13]. The ductile strength $\left(\tau_{d}\right)$ is calculated from the dislocation creep flow law at a given average strain rate over the subducted lithosphere $\left(\dot{\varepsilon}=10^{-15} s^{-1}\right)$, and thus depends on the temperature:

$$
\tau_{d}=\sigma_{1}-\sigma_{3}=\left[\frac{\dot{\varepsilon}}{A}\right]^{1 / n} \cdot \exp \left(\frac{Q}{n \cdot R \cdot T}\right)
$$

where $A, Q, n$ the pre-exponential constant, the activation energy and the stress exponent, respectively; and are given in Table 2 for both the crust and the mantle. In contrast to Van den Beukel, we do not assume any rheological differences between the upper and lower crust, so that the conditions for stacking can be studied in the absence of crustal heterogeneities (e.g. weak upper crust versus strong lower crust). Three sets of ductile rheological parameters for the crust (Table 2) will be used in this study: Dry Plagioclase (strong felsic crust), Mafic Granulite (strong mafic crust) and Wet Quartz (weak crust).

\subsection{Stacking prediction}

The detachment of a crustal unit from the subducted lithosphere is modeled here by comparing the applied net stress, hereafter denoted as $\sigma_{A}$, and the margin strength $\tau$. Stacking occurs when the strength becomes lower than the applied stress:

$$
\text { Stacking if: } \quad \tau \leq \sigma_{A}
$$

Numerical results will quantify the time evolution of the margin strength $\tau$ in 2D. The applied net stress $\sigma_{A}$ has been calculated analytically and is the sum of tectonic stress $\sigma_{T}$, friction stress $\sigma_{F}$ and buoyancy stress $\sigma_{B}$ :

$$
\sigma_{A}=\sigma_{B}+\sigma_{T}+\sigma_{F}
$$

Note that the buoyancy force is commonly the only force accounted for in subduction analyses [52, 30, 31, 35, 1, 22. This assumption should be relevant in the study of lithosphere plates sinking into the mantle at great depths (200$400 \mathrm{~km}$ ), where the mantle is supposed to behave like a fluid. In the present analysis, we account for two other forces since most of the evolution of the subducted margin occurs within the overlying lithosphere. Appendix B gives a full description of the three stresses used to define the applied net stress that are shown in Figure 3 as a function of the burial depth for a given subduction velocity and subduction dip angle. The tectonic stress $\sigma_{T}$ is assumed to be at its maximum during the burial in the overlying crust, which is the elastic part of the overlying lithosphere. At greater burial depths, the tectonic stress progressively decreases to zero at the lithosphere-asthenosphere boundary (figure 3). The maximum value of $\sigma_{T}$ is defined by the integral of the strength of a margin prior to subduction divided by the lithosphere thickness. Thus, this value corresponds to the necessary stress to deform the passive margin that enters subduction [13, 64, 63]. The friction stress $\sigma_{F}$ is defined as the Mohr-Coulomb shear stress along the subduction fault plane. This stress is therefore a function of the overlying weight, which increases with burial, and of the friction coefficient of the subduction plane denoted $\mu_{s}$. This friction coefficient is constant and at its maximum in the first $30 \mathrm{~km}$ of the subduction plane and then progressively decreases to zero at the lithosphere-asthenosphere boundary of the overlying plate. In the parametric study that follows, we will investigate the role of that friction coefficient $\mu_{s}$ in the stacking process. During burial in the overlying crust, $\sigma_{F}$ increases with an increase in the overlying weight. During burial in the overlying mantle, the increase in $\sigma_{F}$ is less pronounced because the increase in the overlying weight is counter-balanced by a decrease in the friction coefficient. This competing effect leads to a decrease in $\sigma_{F}$ at burial depths greater than approximately $50 \mathrm{~km}$. Finally, $\sigma_{F}$ becomes zero in the overlying asthenosphere. The buoyancy stress $\sigma_{B}$ is equal to zero during the burial in the 


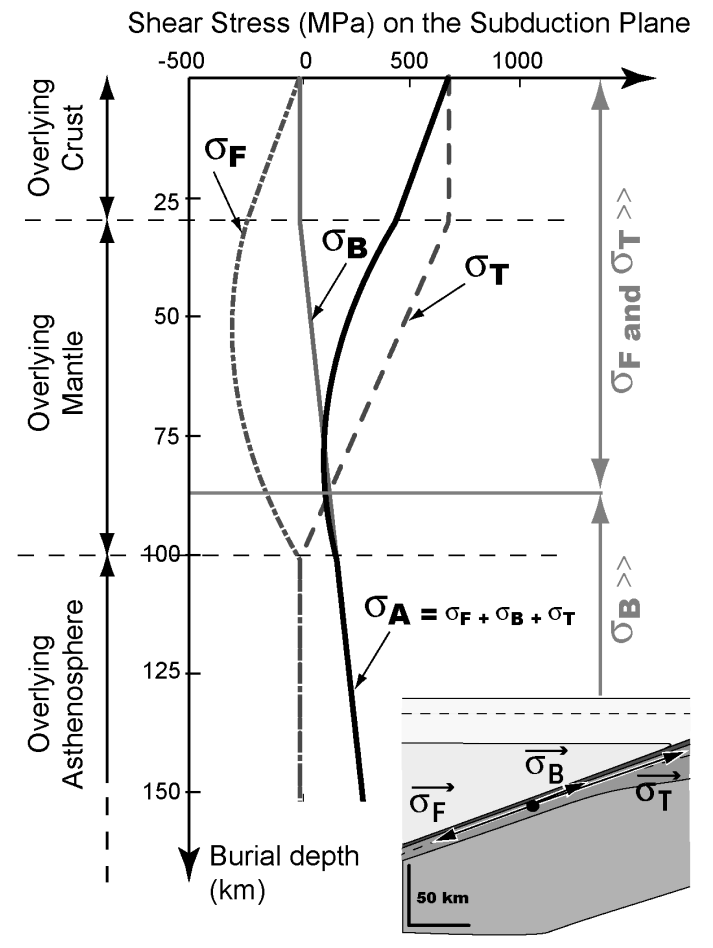

Figure 3: Evolution of the applied stresses on the subduction zone for a subduction dip angle and velocity $\left(\alpha=30^{\circ}\right.$ and $V=1 \mathrm{~cm} . \mathrm{y}^{-1}$ ) as a function of the burial depth. $\sigma_{T} \sigma_{F}$ and $\sigma_{B}$ are the tectonic stress, the friction stress and the buoyancy stress, respectively, which are defined from the three forces presented in Figure 2. The full definition of these three stresses is provided in Appendix B. At an increasing burial depth, the applied net stress that is the sum of these three stresses $\left(\sigma_{A}=\sigma_{F}+\sigma_{T}+\sigma_{B}\right)$ first decreases due to the dominance of both the friction stress $\sigma_{F}$ and the tectonic stress $\sigma_{T}$ and then increases due to the dominance of the buoyancy stress $\sigma_{B}$. See text for further details. 


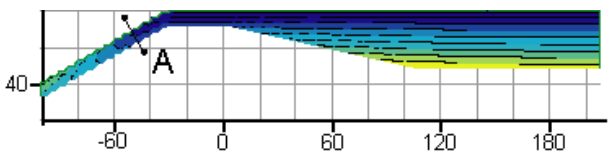

3 My
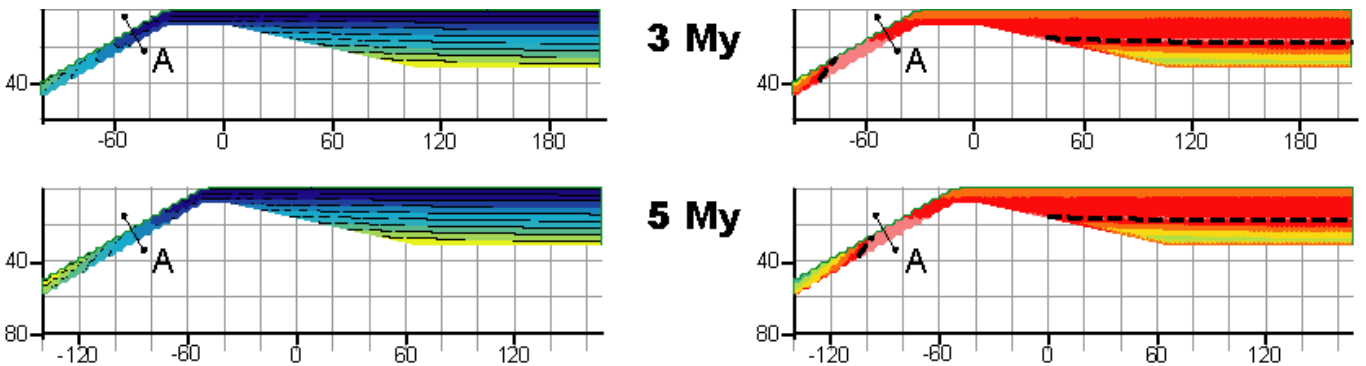

5 My
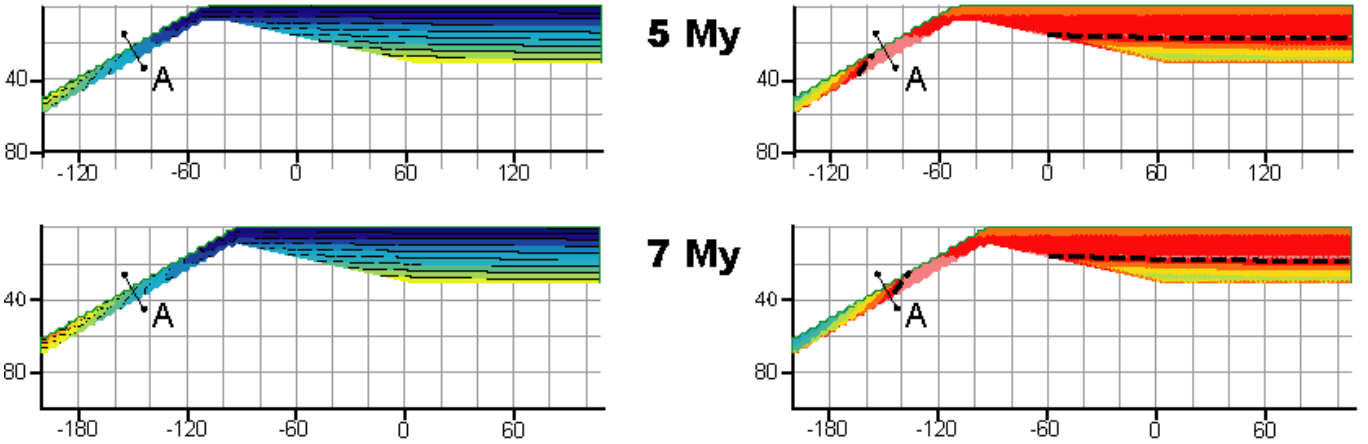

7 My
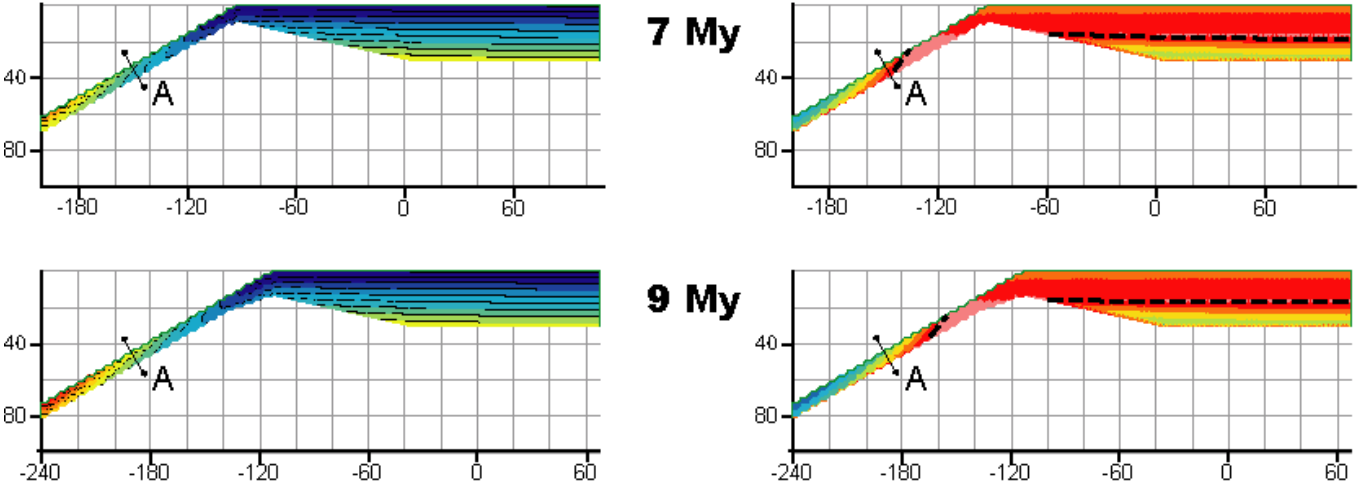

9 My
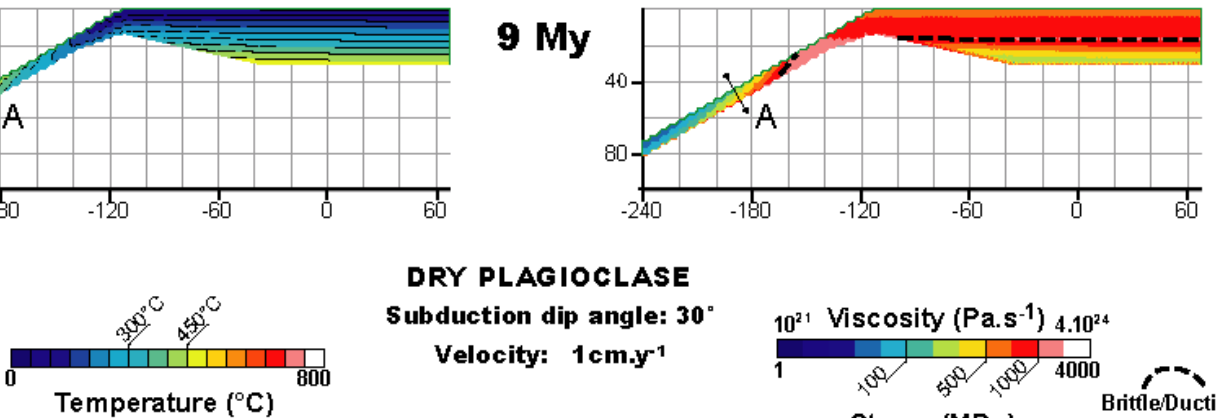

DRY PLAGIOCLASE

Subduction dip angle: $30^{\circ}$

Velocity: $1 \mathrm{~cm} \cdot \mathbf{y}^{-1}$

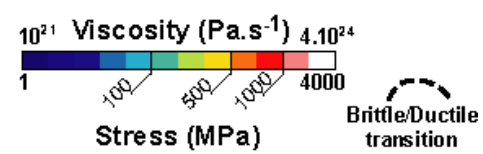

Figure 4: Evolution of temperature (left) and strength (right) in the subducted crust for burial times of 3 Ma, $5 \mathrm{Ma}, 7 \mathrm{Ma}$ and $9 \mathrm{Ma}$. Dry plagioclase is used to compute the crustal strength (Table 2) and the subduction dip angle and velocity are $\alpha=30^{\circ}$ and $V=1 \mathrm{~cm} \cdot y^{-1}$, respectively. The cross-section A will be used to calculate the mean strength $\tau_{A}$ at $50 \mathrm{~km}$ from the edge of the margin in Figure 5 . The Brittle - Ductile transition is overprinted on the strength with dashed lines.

overlying crust because there is no density contrast between the subducted crust and the overlying crust. Then, the buoyancy stress increases linearly with the burial depth because the length of the crustal material entering the overlying mantle is increasing linearly [56].

The competing effects of these three stresses imply that during the burial history, the applied net stress $\sigma_{A}$ along the subducted margin first decreases at burial depths lower than $80-90 \mathrm{~km}$, because the tectonic stress dominates at these depths (Figure 3), and then, increases with larger burial depths when buoyancy stress is dominant. The numerical modeling will now allow us to quantify the strength evolution of the subducted margin and therefore, to predict stacking (e.g. when the material strength becomes lower than the applied net stress).

\section{2D Thermal and Material Strength Evolution}

Figure 1 presents the temperature and strength of the crustal part of the passive margin undergoing continental subduction for the reference model at four different ages after continental subduction has begun: $3 \mathrm{Ma}, 5 \mathrm{Ma}$, $7 \mathrm{Ma}$ and $9 \mathrm{Ma}$. The geometrical, thermal and rheological parameters for the reference model are: subduction dip angle $\alpha=30^{\circ}$, subduction velocity $V=1 \mathrm{~cm} \cdot \mathrm{y}^{-1}$, diffusive layer conductivity $k_{s}=1.75 W \cdot \mathrm{m}^{-1} \cdot K^{-1}$, crustal conductivity $k_{c}=2.1 \mathrm{~W} \cdot \mathrm{m}^{-1} \cdot K^{-1}$, Dry Plagioclase for the ductile rheology and the brittle crust rheology $\mu=0.7$. For the applied net stress, the only parameter that can vary is the friction coefficient of the subduction plane that is for the reference model $\mu_{s}=0.7$. The role of these parameters in the stacking processes will be discussed later in the parametric study and is summarized in Table 3. In the reference model, at 3 Ma, most of the margin has not been subducted. In the non-subducted continental crust, the temperature distribution has not changed from the initial state and thus, temperature increases with depth. As a consequence, the rheological layering of the non-subducted margin crust yields a brittle-ductile transition at a depth of $20 \mathrm{~km}$, which is typical for Dry 
Plagioclase [56]. Only approximately an $80 \mathrm{~km}$-long part of the margin is subducted where the temperature distribution drastically changes from the initial conditions. Due to of the heating from the overlying lithosphere, the temperature decreases with depth within the subducted crust, defining a classical reverse temperature profile. Along the margin, the heating is greater at greater burial depths. The margin strength is calculated from the $2 \mathrm{D}$ temperature distribution as the minimum between the brittle and ductile stresses (equations 2 and 3 ). The progressive heating from the overlying lithosphere will induce a decrease in the ductile stress, while the burial induces an increase in the brittle stress. As a consequence, an originally brittle crustal material can become ductile during the burial history. This feature is observed at $3 \mathrm{Ma}$ only in the deeper part of the subducted passive margin where the upper part of the crust has become weak and ductile, as imaged by the brittle-ductile transition that almost occurs at $300^{\circ} \mathrm{C}$ (Figure 4 ). Continental subduction is thus marked by two strength gradients (Figure (4): first, along the subduction zone, the strength decreases with increasing burial depths, and second, perpendicular to the subduction zone, the strength increases with depth due to a temperature inversion. For larger times (e.g. $5 \mathrm{Ma}, 7 \mathrm{Ma}$ and $9 \mathrm{Ma}$ - Figure 4 ), there is an increase in the length of the crust that has been subducted. Because the brittle-ductile transition remains at the same depth (isotherm $300^{\circ} \mathrm{C}$ - Figure 1 ), the length of the ductile material increases with time, as already discussed by Hacker [31]. A material point initially located near the surface, and that is ongoing subduction, will therefore become ductile at a depth of around $20-30 \mathrm{~km}$. In contrast, a material point initially located at a depth of $10 \mathrm{~km}$ will become ductile at a larger burial depth of $40 \mathrm{~km}$.

In summary, the subducted continental margin is progressively heated by the overlying lithosphere during continental subduction. This induces the reverse temperatures and strength profiles in the subducted crust and thereby, a strong thermal weakening in the upper part of the subducted continental crust. On the lithosphere scale, the two strength gradients, along the subduction zone and perpendicular to the subduction zone, are progressively enhanced with time during the burial history. For the reference model, only 3 Ma were needed to significantly reduce the strength so that the material became ductile. This evolution of material strength strongly depends on slab velocity, as it will be discussed below. In any case, the material strength never reaches values lower than $10 \mathrm{MPa}$. The viscosity of the subducted crust is therefore always greater than $10^{22}-10^{23} \mathrm{~Pa}$.s, using an overall strain rate of $\dot{\varepsilon}=10^{-15} \mathrm{~s}^{-1}$. However, as already discussed, a fully coupled 2D thermo-mechanical modeling would provide a large variation in the strain rate within the deforming slab and hence, in the viscosity. Such models could therefore predict values of slab viscosity that can be much lower than those obtained with the present thermal and strength modeling, which only accounts for a bulk and homogeneous strain rate [23]

\section{Mechanical Analysis of the Stacking of HP-LT Crustal Units}

Stacking conditions could be estimated by comparing the margin strength with the applied net stress along the subduction plane. A 1D analysis is presented first, in order to explain the approach used to predict stacking. Second, a 2D analysis, based on the 2D thermal and strength modeling, is presented in order to discuss the geometry of the stacked areas.

\subsection{D analysis}

Based on the 2D strength evolution of the margin through time, we calculated the mean value of the crustal strength in the middle of the stretched part of the margin (local cross-section A, Figure 4 ), which is denoted $\tau_{A}$. The values of $\tau_{A}$ and the applied net stress $\sigma_{A}$ for the reference model are plotted as a function of the burial depth in Figure 5. Stacking would occur within the local cross section A when $\tau_{A}$ becomes lower than $\sigma_{A}$ (equation 4). In the first stage of the burial history, the material remains brittle and its strength increases with burial depth, because of the pressure sensitivity of the brittle rheology (equation 2). At $5 \mathrm{Ma}, \tau_{A}$ is at its maximum at around $2000 \mathrm{MPa}$. Then, the heating is sufficient to weaken the material, which then becomes ductile. Between 5 Ma and $7 \mathrm{Ma}$, the mean material strength drastically decreases from $2000 \mathrm{MPa}$ to $300 \mathrm{MPa}$ (Figure 5). Stacking could occur here at around $7 \mathrm{My}$ and at a depth of $40 \mathrm{~km}$, when the material strength $\tau_{A}$ is lower than the applied net stress $\sigma_{A}$. This depth is the minimum depth at which stacking could occur, and defines the minimum stacking depth (MSD) in the following. Stacking was not possible before because the material was entirely brittle and therefore, its strength increased with burial depth. Thus, stacking is only allowed when the material becomes ductile and thereby weakens with ongoing heating. These results pointed out the necessity to account for the three stresses in order to define the applied net stress (Figure 3). If buoyancy stress was the only stress, then $\sigma_{A}$ would have been too low to trigger stacking at depths lower than 55-60 km (Figures 2, 3 and 5). It is therefore necessary to account for tectonic stress, which increases the value of the applied net stress at low burial depths, in order to explain the stacking of crustal pieces at depths lower than 55-60 km (i.e. 1.5-1.7 GPa), as may occur in natural cases. 


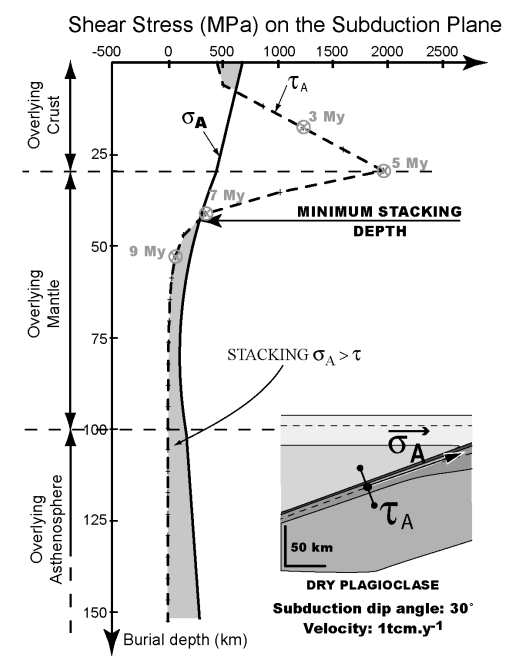

Figure 5: $1 \mathrm{D}$ evolution of the applied net stress $\sigma_{A}$ and the material strength $\tau_{A}$, calculated on the local section A of the 2D models of Figure 4 , as a function of the burial depth. Dry plagioclase is used to calculate the crustal strength (Table 2); the subduction dip angle and velocity are $\alpha=30^{\circ}$ and $V=1 \mathrm{~cm} . y^{-1}$, respectively. Stacking is possible when the material strength becomes lower than the applied net stress (grey shaded areas).

Thus, this 1D analysis reveals that the progressive heating of the slab crust during continental subduction leads to a thermal weakening and a subsequent drastic decrease in the material strength. This thermal weakening is sufficient to allow for the detachment of a crustal unit from the subducted margin at a critical depth hereafter called the minimum stacking depth (MSD). This detachment is not modeled here, but would correspond to ductile shearing at base of the base of the crustal unit, as will be discussed in the $2 \mathrm{D}$ analysis.

\subsection{D stacking analysis}

\subsubsection{Potential stacking area}

Assuming that the applied net stress $\left(\sigma_{A}\right)$ is constant over a vertical section in the subducted crust, we can plot, in $2 \mathrm{D}$, the ratio of the applied net stress along the subduction plane $\sigma_{A}$ over the margin strength $\tau$, which is inferred from the 2D numerical results (Figure 6). Stacking is not possible if this ratio is lower than $1\left(\log \sigma_{A} / \tau<0\right.$ dark domain in Figure 6). In 2D, the minimum stacking depth (MSD) is the base of the colored areas in Figure 6 and is at a burial depth of $30 \mathrm{~km}$ at the top of the subducted crust and at approximately $40 \mathrm{~km}$ in the deep crust. This difference is explained by a reverse strength profile (e.g. lower strength in the top of the subducted crust with respect to the deep crust, Figure 41. The position of the MSD does not change with time because the overall $2 \mathrm{D}$ thermal state of the subduction does not evolve with time. The progressive heating of the subducted margin with the burial history induces an increase in the length of the stacking area $\left(\log \sigma_{A} / \tau>0\right)$. In $1 \mathrm{D}$, stacking was predicted to occur only after $7 \mathrm{Ma}$, while in 2D, stacking could occur at $3 \mathrm{Ma}$. This is because in the $1 \mathrm{D}$ analysis, we used a mean value of the margin strength at a given position (point A plotted in Figure 6), which is compared to $\sigma_{A}$, while in 2D, the difference between the applied net stress $\sigma_{A}$ and the strength $\tau$ was calculated for each material point.

\subsubsection{Length and thickness of detached crustal units}

Based on the definition of the potential stacking area, it is possible to define the shape (i.e. length and thickness) of the detached continental unit as follows. Within the subducted crust, a sharp strength gradient is observed above the MSD (Figures 6 and (4). The top of the potential stacking area is significantly weaker than its base, which will therefore be less deformed during the stacking processes. Again, the detachment process, e.g. deformation, is not modeled here. However, the 2D thermal and strength models provided important information on the strength gradients both within and along the subduction zone that would have a major impact on the deformation pattern. The detachment of a crustal unit would correspond to a strong ductile shearing of the weakened crustal potential stacking area within the subduction zone. The strength gradients within the continental slab would induce a heterogeneous deformation, and the relatively strong base of the potential stacking area would be little deformed. As a consequence, it is unlikely that the entire potential stacking area will form a future detached unit, and thus, 

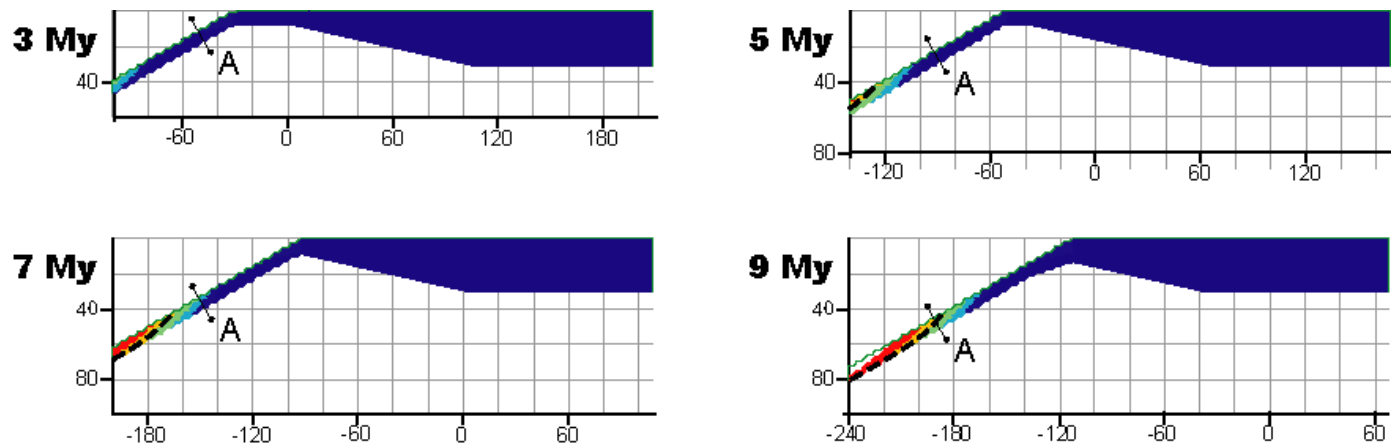

DRY PLAGIOCLASE

Subduction dip angle: $30^{\circ}$

Velocity: $1 \mathrm{~cm} \cdot \mathrm{y}^{-1}$
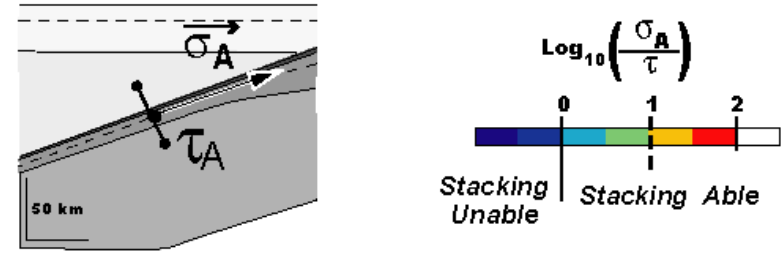

Figure 6: 2D evolution of the ratio, in log scale, of the applied net stress $\left(\sigma_{A}\right)$ over the material strength $(\tau)$, providing the evolution of the $2 \mathrm{D}$ potential stacking area (light blue to white domains). Dry plagioclase is used to calculate the crustal strength (Table 2); the subduction dip angle and velocity are $\alpha=30^{\circ}$ and $V=$ $1 \mathrm{~cm} . \mathrm{y}^{-1}$, respectively. The dashed line marks the area taken into account for the length and thickness estimation $\left(\log \left(\sigma_{A} / \tau\right) \geq 1\right)$. See text for further details.

we have proposed that the base of the future detached crustal unit is the region where the ratio $\sigma_{A} / \tau$ is equal to 10 (i.e. dashed line in Figure 6). On these bases, we can measure the length and thickness of the future detached unit directly from the $2 \mathrm{D}$ results. The upper limit of the unit has a dip angle that is higher than the subduction dip angle. This implies that the length of the detached unit is larger in the top of the subducted crust than in the deep subducted crust. Similarly, the thickness of the unit is smaller at shallower levels than at deeper levels. To avoid these variations and to have a single value for the thickness and length, we have chosen to use the mean value for the thickness and length.

For the reference model, the lengths and thicknesses of the future stacked units are shown in Figure 7 as a function of the burial depth (straight line, $\alpha=30^{\circ}$ and $\mathrm{V}=1 \mathrm{~cm} \cdot \mathrm{y}^{-1}$ ). The length increases with burial depth. Because the minimum stacking depth (MSD) does not change with time, the length of the potential stacking area, and thereby the length of the future detached unit, increases with burial depth. Similarly, the thickness of the stacked unit increases between burial depths of $30 \mathrm{~km}$ (MSD) and 60-70 km, and then, is almost constant at its maximum value (e.g. crustal thickness of $10 \mathrm{~km}$ for the thinned part of the margin).

In summary, this $2 \mathrm{D}$ thermal and strength modeling predicts the possible detachment of the ductile weakened thin and long upper-crustal units without evoking a vertical crustal heterogeneity. This is the first novelty of this modeling, compared to Van den Beukel's model [5], which explains stacking with lower crustal rheological heterogeneities. The second novelty of this study is that the decoupling of the HP-LT crustal units could only occur in the ductile regime due to a thermal evolution with burial. The detachment should occur along a major shear zone at the base of the unit due to large strength gradients both along and perpendicular to the subduction plane.

\section{Parametric Study}

Following the analyses made for the reference model (i.e. the straight lines in Figure 7), we have performed a series of $2 \mathrm{D}$ models in order to quantify the role of the geometrical, rheological and thermal parameters in defining the HP-LT crustal unit length and thickness (Table 3).

\subsection{Role of subduction dip angle $(\alpha)$ and velocity $(V)$}

Figure 7 presents unit length and thickness as a function of burial depth for $\mathrm{V}=1 \mathrm{~cm} \cdot \mathrm{y}^{-1}$ for four values of the subduction dip angle $\alpha\left(10^{\circ}, 20^{\circ}, 30^{\circ}, 40^{\circ}\right)$ and for $\alpha=30^{\circ}$, for four values of $\mathrm{V}\left(1 \mathrm{~cm} \cdot \mathrm{y}^{-1}, 2 \mathrm{~cm} \cdot \mathrm{y}^{-1}, 3 \mathrm{~cm} \cdot \mathrm{y}^{-1}, 4 \mathrm{~cm} \cdot \mathrm{y}^{-1}\right)$. The burial depths at which the unit lengths and thicknesses become non-zero are the minimum stacking depths (MSD). The MSD value is relatively similar for the different subduction velocity $(V)$ and subduction dip angle 

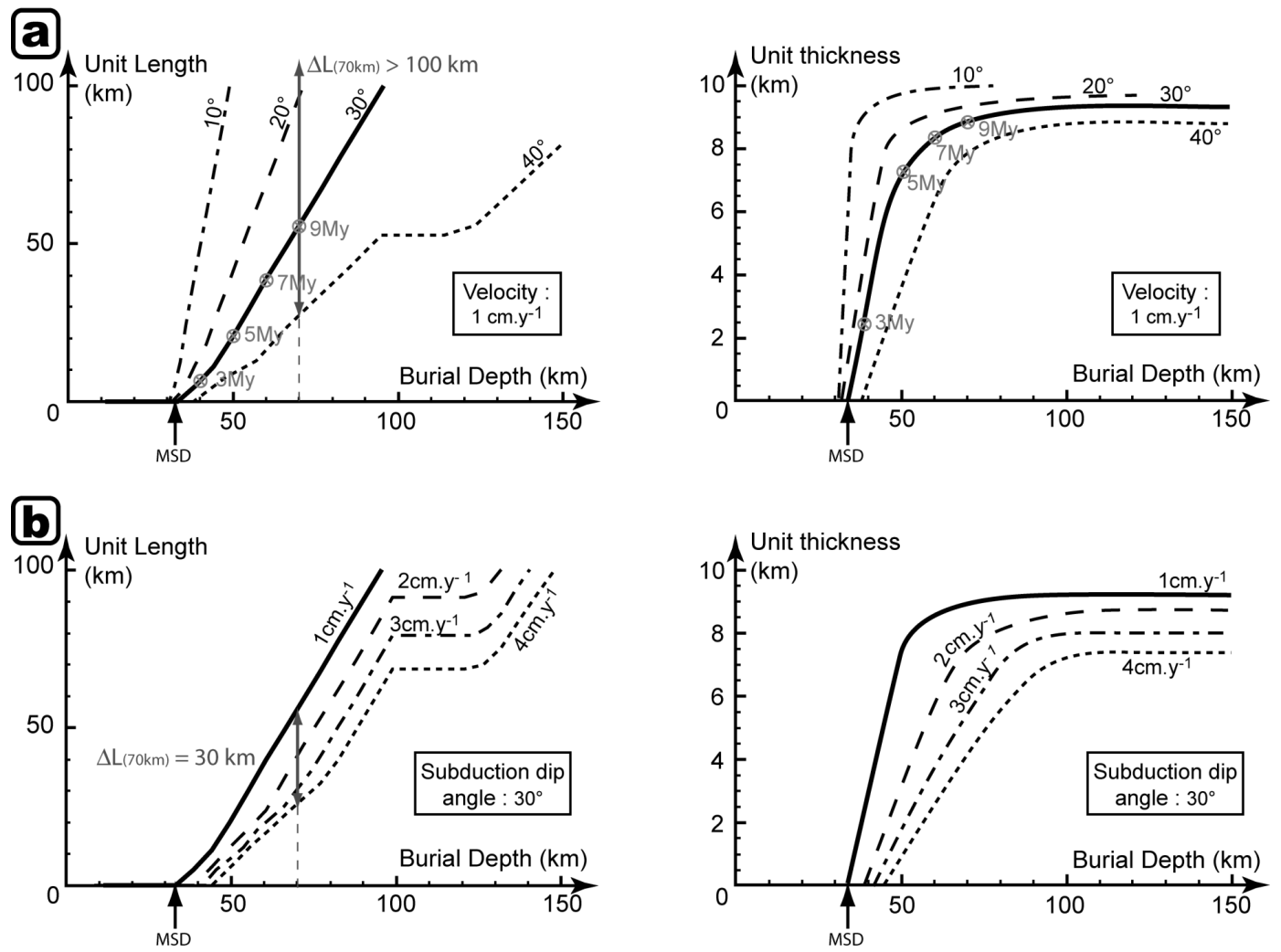

Figure 7: Unit length (left) and thickness (right) inferred from the 2D thermal and strength models in Figure 4 , as a function of burial depth. a-for a velocity equal to $1 \mathrm{~cm} . y^{-1}$ and for four subduction dip angle values $\left(10^{\circ}, 20^{\circ}\right.$, $30^{\circ}, 40^{\circ}$ - top part); and b-for a subduction dip angle equal to $30^{\circ}$ and for four velocity values $\left(1 \mathrm{~cm} \cdot \mathrm{y}^{-1}, 2 \mathrm{~cm} \cdot \mathrm{y}^{-1}\right.$, $3 \mathrm{~cm} \cdot \mathrm{y}^{-1}$ and $4 \mathrm{~cm} \cdot \mathrm{y}^{-1}$ - bottom part). MSD: Minimum Stacking Depth for the reference model. The vertical arrows $(\Delta L(70 \mathrm{~km}))$ represent the variation of the unit length at a burial depth of $70 \mathrm{~km}$ induced by the variation in the subduction dip angle (top) and the subduction velocity (bottom) The $(\Delta L(70 \mathrm{~km})$ ) values are reported in Table 3 for the entire set of parameters studied. 
$(\alpha)$ values and ranges between 30 and $40 \mathrm{~km}$. The MSD increases weakly at a higher subduction velocity and/or subduction dip angle. At low burial rates (low dip angle/low subduction velocity), the thermal evolution of the subducted margin is slow enough to allow an almost thermal equilibrium within the subduction zone; and hence, the subducted margin will be heated early in its burial evolution, permitting stacking at lower burial depths. In contrast, an increase in the burial rate will favour an adiabatic evolution of the subducted margin and thus, stacking will occur at larger burial depths.

At the same burial depth, the unit lengths and thicknesses are smaller for larger burial rates (either a larger $\mathrm{V}$ or a larger $\alpha$ ). As explained above, a low burial rate favours margin heating and a subsequent strength decrease, leading to a rapid increase in the unit length and thickness with burial depth. In contrast, the length and thickness of the stacked unit are reduced for larger burial rates due to more adiabatic evolution of the subducted margin. The variation in the length of the units $(\Delta L)$, calculated at a $70 \mathrm{~km}$ burial depth (e.g. $2.0 \mathrm{GPa}$ ) is defined as a criteria to quantify the impact of the considered parameters on the stacking process. In the reference model at $2.0 \mathrm{GPa}$, the unit length is $L(70 \mathrm{~km})=55 \mathrm{~km}$ (Figure 7, straight line). The variation of the length of the units with the subduction dip angle $\left(10^{\circ}\right.$ to $\left.40^{\circ}\right)$, denoted as $\Delta L_{\alpha}(70 \mathrm{~km})$ is greater than $100 \mathrm{~km}$. The variation of the length of the units with the subduction velocity $\Delta L_{V}(70 \mathrm{~km})$ is only $30 \mathrm{~km}$.

\subsection{Role of rheological and thermal parameters}

\subsubsection{The role of ductile crust rheology}

Three crustal rheologies are used for the 2D models (Figure 8a): Dry Plagioclase (reference model, [56]), Wet Quartz 50] and Mafic Granulite [65]. The increase in unit length with burial depth is rather similar for the three crustal rheologies (Figure $8 \mathrm{a}$ ), but the minimum stacking depth is strongly controlled by the crustal rheology. The stronger the rheology, the deeper the minimum stacking depth. With the same thermal evolution of the margin, a strong rheology will delay the time at which the subducted material will become ductile and thus, will increase the depth at which the margin strength drastically decreases. As a consequence, the minimum stacking depth will be larger for a stronger crustal rheology.

The variation of the length of the units with the crustal rheology at $2.0 \mathrm{GPa}$ (wet quartz, dry plagioclase or mafic granulite) is large: $\Delta L_{\text {rheo }}(70 \mathrm{~km})=90 \mathrm{~km}$.

\subsubsection{The role of the coefficient of friction $\left(\mu_{s}\right)$}

Figure \&b presents unit length as a function of burial depth for two subduction zone friction coefficient values, which define the friction stress for the applied net stress (equation 5): $\mu_{s}=0.7$, which is a common value for crustal material at surface [56], and $\mu_{s}=0.1$ which corresponds to soft and wet material, such as hydrated sediments in depths [13. A decrease in $\mu_{s}$ will therefore decrease the absolute value of the applied friction stress along the subduction plane and hence, will increase the applied net stress $\sigma_{A}$ because the friction stress has a negative contribution to the applied net stress $\sigma_{A}$ (Appendix A). As a consequence, a decrease in the friction coefficient $\mu_{s}$ will inhibit stacking and will therefore increase the Minimum Stacking Depth (MSD). However, changes in the MSD are not significant; compared to the role of ductile crust rheology (Figure 8). At a burial depth larger than the MSD, an increase in the crustal unit length is moreover very similar for the two friction coefficient values $\left(\mu_{s}\right)$. The variation in the length of the units with the friction coefficient (0.1 to 0.7) is rather small: $\Delta L_{\mu_{s}}(70 \mathrm{~km})=10 \mathrm{~km}$. The friction coefficient of the subduction plane does not have a significant influence on the stacking process.

\subsubsection{Role of thermal parameters}

The role of mantle heat flux $\left(20<q_{m}<40 \mathrm{~mW} \cdot \mathrm{m}^{-2}\right)$, radiogenic heat production $\left(0.0<r<2.0 \mu W . m^{-3}\right)$, thermal conductivity of the crust $\left(2.1<k_{c}<2.5 W \cdot m^{-1} \cdot K^{-1}\right)$ and of the diffusion layer $\left(1.0<k_{s}<2.0 W \cdot m^{-1} . K^{-1}\right)$ on the evolution of unit length with burial depth are summarized in Figure 8. At a given burial depth, an increase in the mantle heat flux $\left(q_{m}\right)$, or an increase in the radiogenic heat production $(r)$ induces an increase in temperature within the subducted crust and thus, enhance stacking process, leading to a decrease in the MSD and an increase in the crustal unit length (Figure $8 \mathrm{c}, \mathrm{d}$ ). In contrast, an increase in the thermal conductivity of the crust $\left(k_{c}\right)$ or of the thermal conductivity of the diffusion layer $\left(k_{s}\right)$ will decrease the temperature within the subducted crust and thereby, inhibits stacking, leading to an increase in the MSD and a decrease in the crustal unit length (Figure \&e,f). Variations in mantle heat flux $\left(q_{m}\right.$ - Figure $\left.8 \mathrm{c}\right)$ have major impact on the upper crustal unit geometry, leading to variation in the unit length $\Delta L_{q_{m}}(70 \mathrm{~km})=35 \mathrm{~km}$ for a variation in heat flux $\left(q_{m}\right)$ from $20 \mathrm{~mW}^{-2} \mathrm{~m}^{-2}$ to $40 \mathrm{~mW} \cdot \mathrm{m}^{-2}$. Variations in the radiogenic heat $(r$ - Figure $8 \mathrm{~d})$, thermal conductivity of the crust $\left(k_{c}\right.$ - figure Be) and thermal conductivity of the diffusion layer $\left(k_{s}\right.$ - Figure $\left.8 \mathrm{f}\right)$ do not significantly influence the increase in unit length and thickness with burial depth: $\Delta L_{r}(70 \mathrm{~km})=5 \mathrm{~km}, \Delta L_{k_{c}}(70 \mathrm{~km})=10 \mathrm{~km}, \Delta L_{k_{s}}(70 \mathrm{~km})=5 \mathrm{~km}$. 


\section{Rheology}

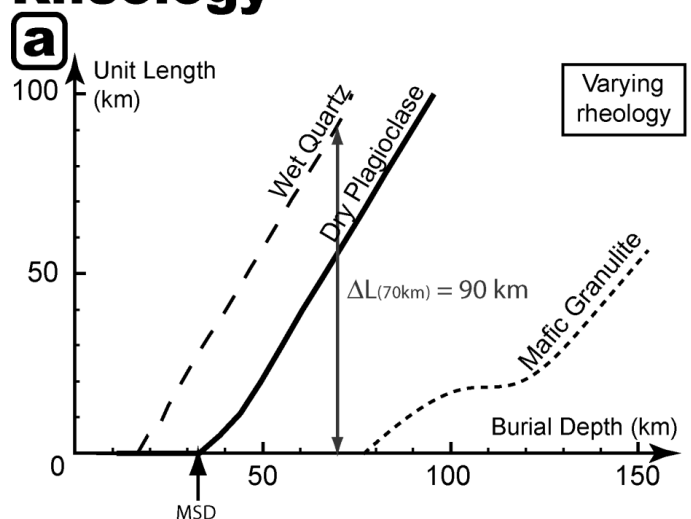

\section{Thermal parameters}
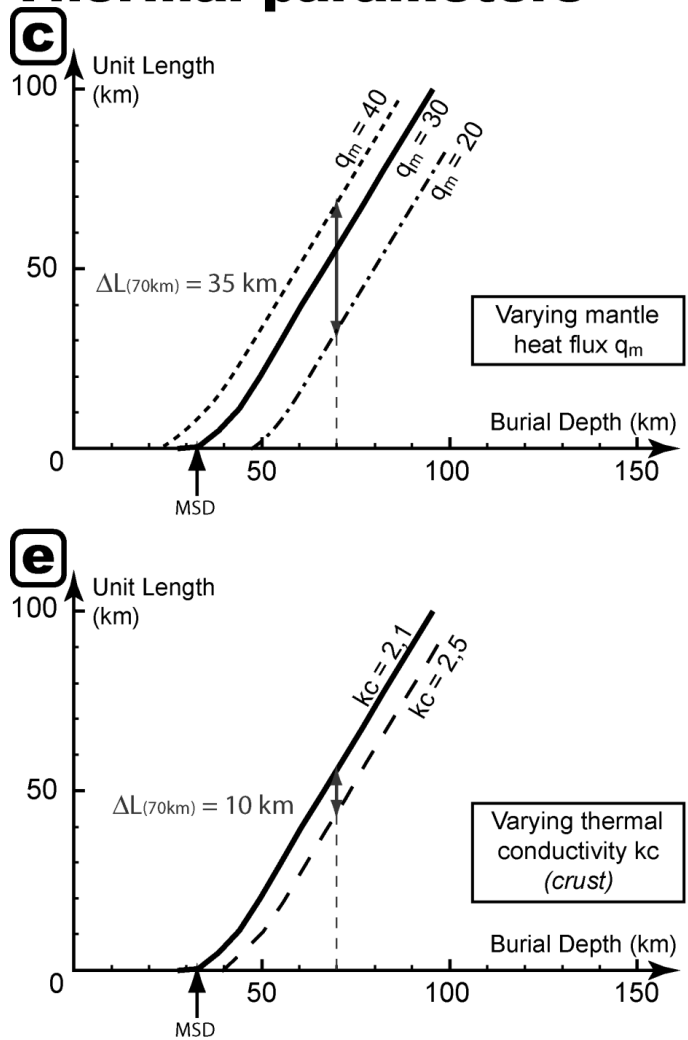
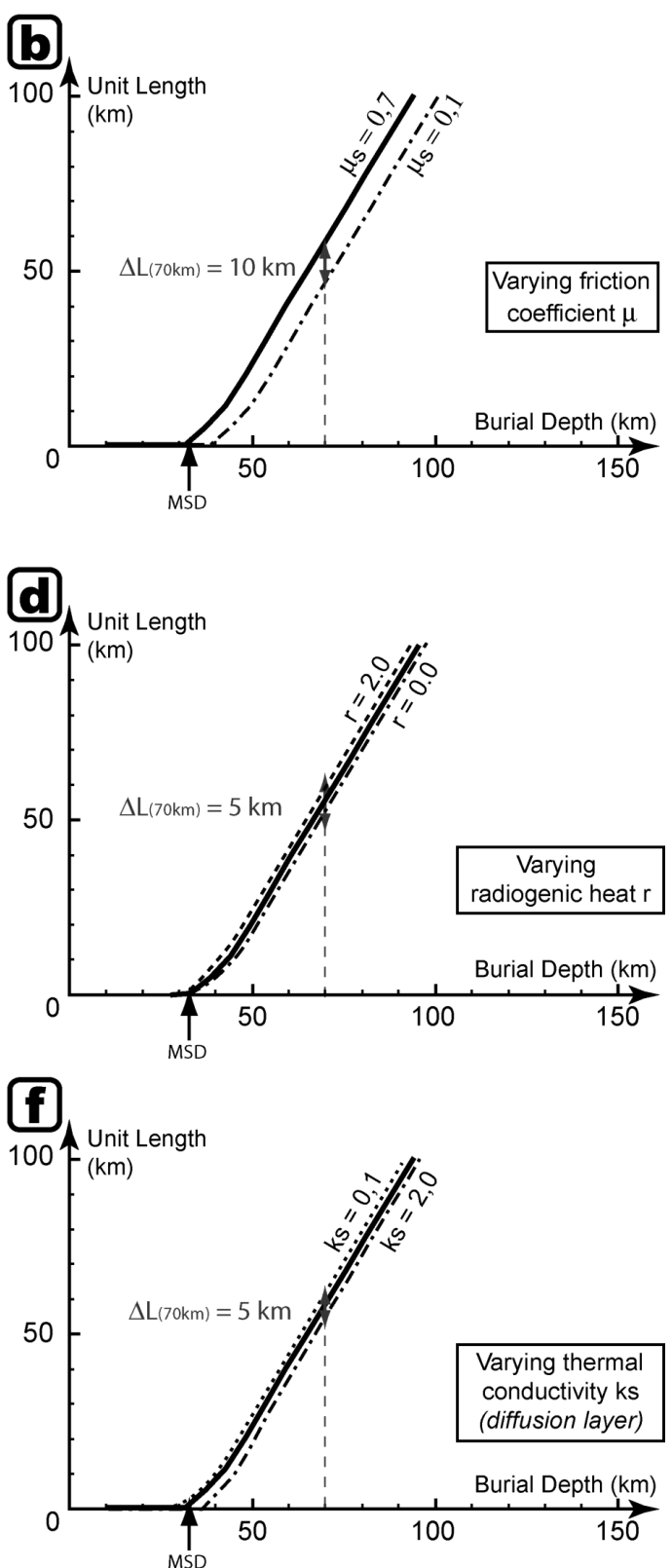

Figure 8: Unit length inferred from the 2D thermal and strength models as a function of the burial depth for: athree different ductile crust rheologies (Wet quartz, Dry plagioclase and Mafic granulite, Table 2), b-two subduction zone friction coefficient $\mu_{s}$ values, c-three mantle heat flux $q_{m}$ values, d-two radiogenic heat production $r$ values, e-two thermal conductivity values for the crust $k_{c}$ and $\mathrm{f}$-two thermal conductivity values for the diffusive layer $k_{s}$. MSD: Minimum Stacking Depth for the reference model. The vertical arrows $(\Delta L(70 \mathrm{~km}))$ show the variation in the unit length implied by the variation in the six parameters studied here. These variations are reported in Table 3 . 


\begin{tabular}{|c|c|c|c|c|c|c|c|c|}
\hline & \multicolumn{2}{|c|}{ Subduction parameters } & \multicolumn{2}{|c|}{ Mechanical parameters } & \multicolumn{4}{|c|}{ Thermal parameters } \\
\hline Parameters & $\begin{array}{c}\text { Dip angle } \\
(\alpha)\end{array}$ & $\begin{array}{c}\text { Velocity } \\
(V)\end{array}$ & Rheology & $\begin{array}{c}\text { Friction coeff. } \\
\left(\mu_{s}\right)\end{array}$ & $\begin{array}{l}\text { Mantle Heat } \\
\text { Flux }\left(q_{m}\right)\end{array}$ & $\begin{array}{c}\text { radiogenic } \\
\text { heat }(r)\end{array}$ & $\begin{array}{c}\text { Crustal thermal } \\
\text { conductivity }\left(k_{c}\right)\end{array}$ & $\begin{array}{c}\text { D.L. thermal } \\
\text { conductivity }\left(k_{s}\right)\end{array}$ \\
\hline unit of meas. & $o$ & $\mathrm{~cm} \cdot \mathrm{y}^{-1}$ & & dimensionless & $m W \cdot m^{-2}$ & $\mu W \cdot m^{-3}$ & $W \cdot m^{-1} \cdot K^{-1}$ & $W \cdot m^{-1} \cdot K^{-1}$ \\
\hline Reference value & 30 & 1 & dry plagio & 0,7 & 30 & 1,0 & 2,1 & 1,8 \\
\hline Range & $10-40$ & $1-4$ & wq, dp, mg & $0,1-0,7$ & $20-40$ & $0-2$ & $2,1-2,5$ & $1,0-2,0$ \\
\hline$\Delta L(70 \mathrm{~km})$ & $>100 \mathrm{~km}$ & $30 \mathrm{~km}$ & $90 \mathrm{~km}$ & $10 \mathrm{~km}$ & $35 \mathrm{~km}$ & $5 \mathrm{~km}$ & $10 \mathrm{~km}$ & $5 \mathrm{~km}$ \\
\hline Controlling role & ++ & + & ++ & - & + & - & - & - \\
\hline
\end{tabular}

Table 3: Respective effect of parameters on the variation of unit length at a $70 \mathrm{~km}$ burial depth. The unit length at a depth of $70 \mathrm{kms}$ is $L_{r e f}(70 \mathrm{~km})=55 \mathrm{~km}$ for the reference model. The rheology abbreviations are as follows: wq: wet quartz, dp: dry plagioclase, mg: mafic granulite

\subsection{Respective effect of the subduction, thermal and mechanical parameters}

Table 3 presents the reference value, the range of variation used for the numerical models presented in this study and the induce variation in the length of the units at a burial depth of $70 \mathrm{~km}(\Delta L(70 \mathrm{~km}))$ for the entire set of parameters studied: subduction dip angle $(\alpha)$ and velocity $(V)$, rheology, coefficient of friction $\left(\mu_{s}\right)$, mantle heat flux $\left(q_{m}\right)$, the radiogenic heat production $(r)$, and thermal conductivity of the crust $\left(k_{c}\right)$ and of the diffusive layer $\left(k_{s}\right)$. This compilation allows us to classify the controlling role of the parameters in order of their importance: 1-dip angle $\alpha$, 2-ductile crust rheology, 3-velocity $V$ and mantle heat flux $q_{m}$ and 4-all the other thermal parameters. Therefore, stacking is primarily controlled by the dip angle of the slab and the ductile rheology. These findings imply that the length or thickness of the HP-LT continental units found in the core of mountain belts may be tentatively used to infer a subduction dip angle at the time of deformation and metamorphism, as will be discussed below.

\section{Comparison with the HP-LT Adula unit}

The Lepontine Dome is part of the central Alps where the stacking of thin and long basement units constituted of upper crustal rocks is found. Contacts between these units consist of major kilometer scale ductile shear zone [2. 42, 44], suggesting that these nappe pile occurred at peak pressure within the ductile regime. These field observations are consistent with our modeling results, which suggest that stacking can only occur when the crustal rocks become ductile. The rocks of those units recorded low-to-high pressure and low temperature metamorphism conditions during the Alpine continental subduction phase [61, 44, 57]. The Alpine subduction velocity at the time of peak metamorphism is estimated at $1.0 \mathrm{~cm} . y^{-1}[60,26,6,63]$. The Adula unit belongs to the Lepontine nappe pile (Figure 9a) and represents the paleo-geographically southernmost part of the European passive margin before the subduction of the Valais trough [58, 60, 47]. The Adula unit consists of a pre-alpine basement constituted of granitoid gneisses and metapelitic schists (Figure 9b), with minor amounts of metasedimentary rocks from the postulated Mesozoic age 34, 39, 45, 46]. Metabasic eclogites and amphibolites occur as boudins between $10 \mathrm{~cm}$ to $100 \mathrm{~m}$ long within basement rocks (Figure 9b). Ultramafic rocks are generally only present at the base and at the top of the nappe [53, 46, 17]. The peak pressure calculated along the Adula unit presents a gradient from the front (North) to the root (South) of the unit [34, 39, 46, 17]. P $P_{\max }$ values estimated in different locations [17 are listed in table 4 . This precise study allows us to quantify the geometry and depth of the Adula unit stacking. For a given point in Figure $9 \mathrm{~b}$, the distance from the front of the nappe is a function of the nappe length and the peak pressure gives the burial depth (Table 4).

The length and thickness of Adula unit are used for comparison with our models. The schistosity of Adula unit is almost horizontal, or slightly east-dipping, except near the Insubric line [12, 44] and it is therefore possible to evaluate the length of this unit on a geological map ass follows (Figure $9 \mathrm{~b}$ ). The thickness is estimated from geological cross-sections, which are constrained by seismic lines and geological surveys [59, 61]. Due to large deformations after stacking, the present day length and thickness of these Penninic units does not represent the length and thickness of the units at the time of the stacking. We have assumed a post-stacking deformation that mostly corresponds to a vertical thinning during stacking and exhumation [41]. The thinning is marked by a foliation parallel to the base and the top of the unit. At the time of stacking, the length was $L_{m} / \beta_{2}$ and the thickness larger $T_{m}$. $\beta_{1}$. $\beta_{1}$ representing the vertical thinning factor and $\beta_{2}$ the horizontal stretching factor, respectively (Figure $9 \mathrm{c}$ ). The assumption of a post-stacking deformation with no volume change yields $\left(T_{m} \beta_{1}\right) \cdot\left(L_{m} / \beta_{2}\right) \cdot\left(l_{m} / \beta_{2}\right)=T_{m} . L_{m} . l_{m}$, and thus, $\beta_{1}=\beta_{2}^{2}$. Based on [41, 17], we used a value between 2.0 and 2.2 for $\beta_{1}$ and between 1.4 and 1.5 for $\beta_{2}$ in this study. 

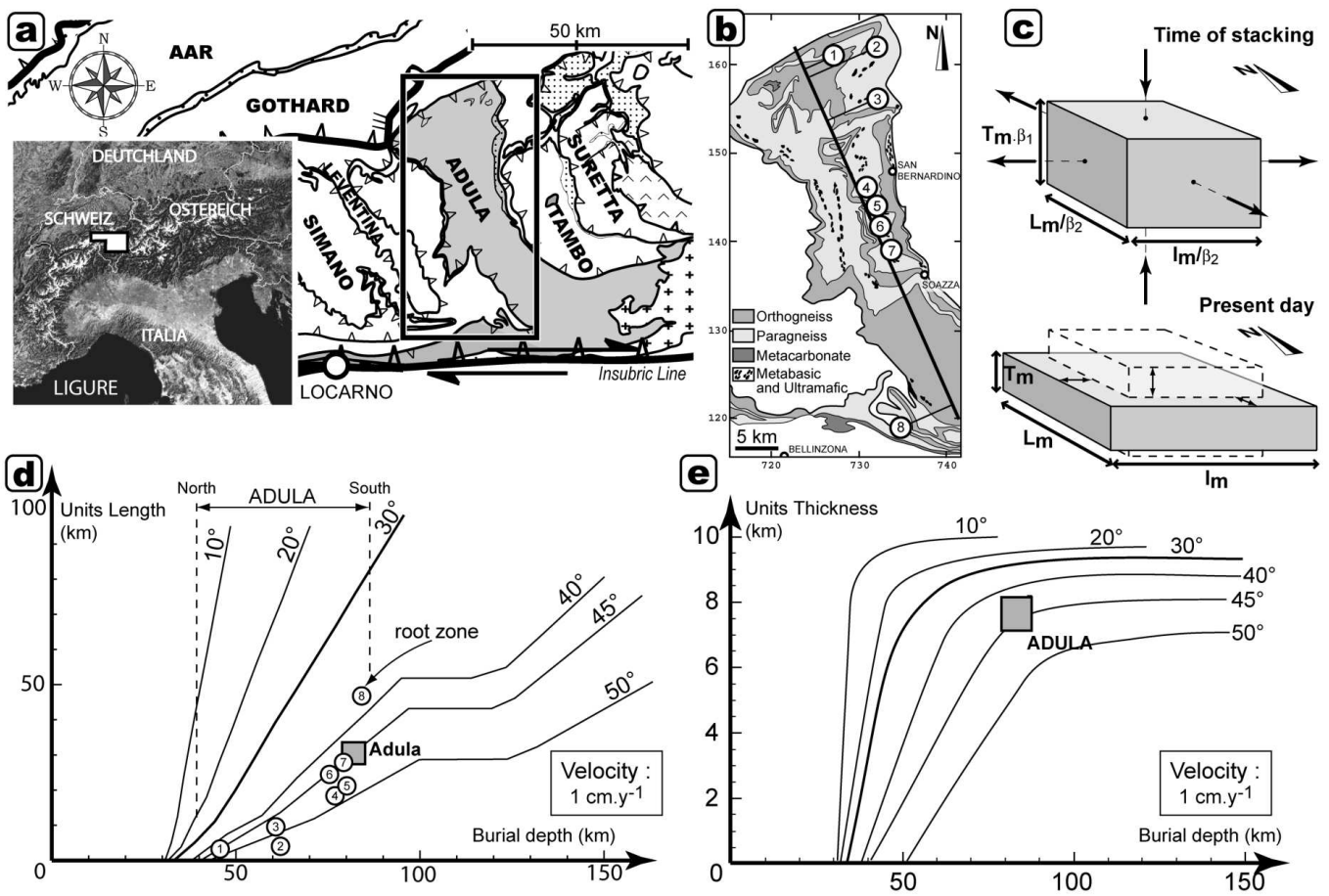

Figure 9: The comparison between the results from our model results and the geometry of the Adula unit inferred from geological and geophysical data allows us to estimate the subduction dip angle at around $45^{\circ}$ for a subduction velocity of $1 \mathrm{~cm} . \mathrm{y}^{-1}$. a-Map, modified after Schmid [61], showing the Lepontine units and the location of the Adula unit. This map was used to estimate the length of the Adula unit. However, the length of the Adula unit at the time of stacking has been modified from the map measurement in order to take in account post-stacking deformation (see c- and text for further details). b-Map, modified after Jenny and Dale [34, 17], showing the location list in Table 14. This map allows us to estimate the distance from the front of the unit for each location. c-Schematic 3D diagram showing the deformation of a unit with no change in volume, which mostly corresponds to a vertical thinning. $L_{m}$ and $T_{m}$ are the present-day measured length and thickness of the unit, respectively. d,e- The unit length (left) and thickness (right) as a function of burial depth is calculated with a Dry plagioclase for a ductile crust rheology, a subduction velocity of $1.0 \mathrm{~cm} . y^{-1}$ and six subduction dip angles $\left(\alpha: 10^{\circ}, 20^{\circ}, 30^{\circ}, 40^{\circ}, 45^{\circ}, 50^{\circ}\right)$. Data (i.e. distance from the front and maximal pressure) from Table are also plotted.

\begin{tabular}{|c|l|c|c|}
\hline $\mathrm{N}$ & Location & $\begin{array}{c}\text { Distance from } \\
\text { the front }(\mathrm{km})\end{array}$ & $\begin{array}{c}\text { Max pressure } \\
(\mathrm{GPa})\end{array}$ \\
\hline 1 & Funt & 2,88 & 1,25 \\
2 & Vals & 3,85 & 1,75 \\
3 & Chichalp & 9,23 & 1,70 \\
4 & Confin & 18,85 & 2,20 \\
5 & Passit & 21,15 & 2,25 \\
6 & d'Arbeola & 23,85 & 2,15 \\
7 & Trescolmen & 26,73 & 2,25 \\
8 & Caurit & 46,92 & 2,40 \\
\hline & Adula unit & $28-33$ & $2,25-2,40$ \\
\hline
\end{tabular}

Table 4: Location, distance to the front and peak pressure (in GPa) of the eight selected points within the Adula unit from Dale and Holland [17]. 


\begin{tabular}{|c|c|c|c|}
\hline Reference & $\begin{array}{c}\text { Mean Dip Angle } \\
\left({ }^{\circ}\right)\end{array}$ & $\begin{array}{c}\text { Velocity } \\
\left(\mathrm{cm} . y^{-1}\right)\end{array}$ & $\begin{array}{c}\text { Temperature } \\
\left({ }^{\circ} \mathrm{C}\right)\end{array}$ \\
\hline Peacock 1996 (model) [52] & 27 & 1,0 & 800 \\
This Study & 30 & 1,0 & 800 \\
\hline \hline Abers 2006 (model) [1] & 27 & $4,5-6,5$ & 600 \\
Hacker 2003 (Costa Ricka) [30] & 29,5 & 5 & 600 \\
This Study & 30 & 5,0 & 580 \\
\hline
\end{tabular}

Table 5: Measured temperature in a subducted crust at a depth of $100 \mathrm{~km}$ from previous numerical models and natural data for different subduction dip angles and velocities. Our numerical estimates are also provided.

We compared the natural Adula example with a set of six models with a varying subduction dip angle at $V=1 \mathrm{~cm} \cdot \mathrm{y}^{-1}$, i.e. the estimated convergence velocity at the time of the peak metamorphism. A Dry Plagioclase rheology was selected for the ductile crust rheology since most rock types from the Adula unit are granitoid. The burial depth, deduced from PT conditions, and both the unit length and thickness are plotted in Figure 9 $\mathrm{d}$ and Figure 9-e, respectively. They were compared to the results from our model. In terms of the unit length, the different natural data are consistent with our modeling and yields a subduction dip angle of $\alpha=45^{\circ}$ (Figure 9 $\mathrm{d}$ ). However, the Caurit location (point 8) is an exception. This can be explained by its position within the root zone, which had been strongly deformed by post-stacking deformation. In terms of the unit thickness, a mean value for the Adula unit also yields a subduction dip angle of $\alpha=45^{\circ}$ (Figure ge). Based on the north-south PT conditions, Dale and Holland [17 have independently quantified the dip angle of the Adula unit during subduction to be approximately $45^{\circ}$, which is consistent with our estimate. Because the Adula is a single HP-LT continental unit, this high level of consistancy between natural data and our model results validate our modelling of continental stacking and allows us to use the HP-LT continental unit geometry and PT conditions as a proxy to infer a subduction velocity at the time of the peak metamorphism. As already discussed, crustal rheology, subduction velocity and mantle heat flux may also have an impact in defining the HP-LT continental unit geometry.

\section{Conclusion}

A 2D conductive model of a continental margin undergoing subduction; has been used to argue that two strength gradients develop within the subducted lithosphere: 1-along the slab, the ductile strength decreases with increasing burial depths and 2- perpendicular to the slab, the ductile strength increases with depth, due to an inverse temperature distribution. The detachment of HP-LT continental units from the subducted margin could occur when the slab strength becomes lower than the applied net stress. This allows the detachment of ductile weakened thin and long upper-crustal units. Due to the strength gradients; both along and normal to the subduction zone, the detachments should localize along the ductile shear zones parallel to the base of the crustal units. These models provide a first step toward a broader study of the piling up of the metamorphic units that are observed in the core of most mountain belts. The thickness and length of the detached crustal units are mainly controlled by the following parameters, in order of their importance: subduction dip angle $(\alpha)$, crustal rheology, mantle heat flux $\left(q_{m}\right)$ and subduction velocity $(V)$. As seen in the results above, geological data such as the geometry and the PT path of HP-LT units could be used to infer either the subduction dip angle, crustal rheology, mantle heat flux or subduction velocity at the time of the deformation and metamorphism. However, additional geological and geophysical constraints relative to the subduction dip angle and velocity, crustal rheology or slab thermal state are required to fully describe the mechanics of continental subduction.

\section{APPENDIX A: Model comparison}

Table 5 presents the estimated temperature at the top of the subducted crust at a $100 \mathrm{~km}$ burial depth based on various numerical models and natural observations for different subduction velocities and dip angles. Our numerical results are consistent with previous models as well as with natural data. This validates the assumption made in this paper to build a simple 2D modeling of the thermal and strength state of continental subduction.

\section{APPENDIX B: Force and stress calculation}

The forces applied to a subducted margin crust are as follows (Figure 2): the Tectonic force $(\vec{T})$ induced by the motion of the overlying lithosphere with respect to the subducted lithosphere, the Buoyancy force $(\vec{B})$ due to the 
burial of the light subducted crust in a heavier mantle, and the Overlying Weight force $(\vec{F})$, which is related to the weight of the overlying lithosphere situated above the subducted crust.

The mechanical equilibrium yields a classical force balance: the sum of all forces must be null and thus, the Acting force $(\vec{A})$, which is the sum of the three applied forces, has to be the opposite of the reaction material force $(\vec{R})$ :

$$
\vec{A}=\vec{T}+\vec{B}+\vec{F}=-\vec{R}
$$

From the acting force $(\vec{A})$, we define the applied net stress $\left(\sigma_{A}\right)$ along the subduction plane as the sum of the following three stresses: tectonic stress $\sigma_{T}$, frictional stress $\sigma_{F}$ and buoyancy stress $\sigma_{B}$.

- The tectonic stress is defined by the projection of the tectonic force $(\vec{T})$ along the subduction plane. The magnitude of the tectonic force $(\|\vec{T}\|)$ is taken as the overall strength of the margin.

$$
\sigma_{T}=\delta(z) \cdot \cos (\alpha) \cdot \int_{0 k m}^{100 k m} \tau(z) d z
$$

with $\int_{0 k m}^{100 k m} \tau(z) d z$ the integral of lithosphere strength and $\alpha$ the dip angle of the subduction (Figure 2). Using Dry Plagioclase and Dry Olivine for the crust and mantle rheology, respectively (Table 2), the integral of the lithosphere strength is equal to $800 \mathrm{MPa}$. The $\delta$ coefficient is used to linearly decrease the tectonic stress along the subduction plane below the overlying crust so that the tectonic stress is at its maximum for subduction within the overlying crust and then decreases linearly to zero at the lithosphere-asthenosphere boundary. To account for that, we assume that:

$$
\delta(z): \begin{cases}\delta(z)=1 & \forall z \leq z_{\text {moho }} \\ \delta(z)=1+\frac{z-z_{\text {moho }}}{z_{\text {moho }}-z_{\text {litho }}} & \forall z>z_{\text {moho }}\end{cases}
$$

with $z$ equaling the burial depth, $z_{m o h o}=30 \mathrm{~km}$ for the Moho depth in the overlying lithosphere, and $z_{\text {litho }}=100 \mathrm{~km}$ for the overlying lithosphere thickness.

- The friction stress $\overrightarrow{\sigma_{F}}$ is define as the product of the friction coefficient of the subduction plane $\mu_{s}$ and the overlying weight force $\vec{F}$, resolved along the subduction fault plane $: \overrightarrow{\sigma_{F}}=\mu_{s} \cdot \vec{F} \cdot \sin (\alpha)$. The overlying weight increases with burial depth and depends on the density of the rocks $\left(\rho_{(z)}\right): F=\rho_{(z)} . g . z$. The Mohr-Coulomb friction coefficient of the subduction plane $\left(\mu_{s}\right)$ is at its maximum during the burial in the overlying crust $\left(z \leq z_{\text {moho }}\right)$. The subduction plane in the overlying crust is considered as a fault plane with a high friction coefficient $\left(\mu_{s}\right)$. In the overlying mantle, this friction coefficient $\left(\mu_{s}\right)$ decreases linearly with depth.

$$
\begin{cases}\sigma_{F}=-\mu_{s} \cdot \rho_{c} \cdot g \cdot z \cdot \sin (\alpha) & \forall z \leq z_{\text {moho }} \\ \sigma_{F}=-\mu_{s} \cdot\left[\rho_{c} \cdot g \cdot z_{m o h o}+\rho_{m} \cdot g \cdot\left(z-z_{m o h o}\right)\right] \cdot \sin (\alpha) \cdot \delta(z) & \forall z>z_{m o h o}\end{cases}
$$

with $z$ equaling the burial depth, $z_{m o h o}=30 \mathrm{~km}$ for the Moho depth in the overlying lithosphere, $\rho_{c}=$ $2800 \mathrm{~kg} \cdot \mathrm{m}^{-3}$ for the crustal density, $\rho_{m}=3000 \mathrm{~kg} \cdot \mathrm{m}^{-3}$ for the mantle density, $g=9,81$ for the constant of gravity, $\alpha$ for the subduction dip angle and $\mu_{s}$ for the Mohr-Coulomb friction coefficient of the subduction plane. The friction coefficient $\mu_{s}$ is left to vary in order to investigate its role in the stacking process. The $\delta(z)$ function is defined in equation 7.

- The Buoyancy stress is directly calculated from the Buoyancy force $\left(\overrightarrow{\sigma_{B}}=\vec{B}\right.$. $\left.\sin (\alpha)\right)$.

$$
\begin{cases}\sigma_{B}=0 & \forall z \leq z_{\text {moho }} \\ \sigma_{B}=\left[\rho_{m}-\rho_{c}\right] \cdot g \cdot\left(z-z_{\text {moho }}\right) \cdot \sin (\alpha) & \forall z>z_{\text {moho }}\end{cases}
$$

with $z$ equaling the burial depth, $z_{\text {moho }}=30 \mathrm{~km}$ for the Moho depth in the overlying lithosphere, $\rho_{c}=$ $2800 \mathrm{~kg} \cdot \mathrm{m}^{-3}$ for the crustal density, $\rho_{m}=3000 \mathrm{~kg} \cdot \mathrm{m}^{-3}$ for the mantle density, and $\alpha$ for the subduction dip angle. The buoyancy is null if the burial depth is less than the Moho depth because there is not a difference of density between the subducted crust and the overlying rocks. Below the Moho, buoyancy increases linearly with burial depth.

\section{References}

[1] G. Abers, P. van Keken, E. Kneller, A. Ferris, J. Stachnik, The thermal structure of subduction zones constrained by seismic imaging: Implications for slab dehydration and wedge flow, Earth and Planetary Science Letters 241 (2006) pp. 387-397. 
[2] T. Baudin, D. Marquer, F. Persoz, Basement-cover relationships in the Tambo nappe (Central Alp, Switzerland): geometry, structure and kinematics, Journal of Structural Geology 15 (3-5) (1993) 543-553.

[3] K. Bauer, et al., Deep structure of the Namibia continental margin as derived from integrated geophysical studies, Journal of Geophysical Research 105(B11) (2000) pp. 25,829-25,853.

[4] C. Beaumont, S. Ellis, J. Hamilton, P. Fullsack, Mechanical model for subduction-collision tectonics of Alpinetype compressional orogens, Geology 24 (8) (1996) pp. 675-678.

[5] J. van den Beukel, Some thermomechanical aspects of the subduction of continental lithosphere, Tectonics 11 (2) (1992) pp. 316-329.

[6] R. Bousquet, M. Engi, G. Gosso, A. Oberhnsli, R. Berger, M. Spalla, M. Zucali, B. Goff, Explanatory notes to the map: metamorphic structure of the alps. transition from western to central alps, Mitt. Osterr. Miner. Ges. 149 (2004) pp. 145-156.

[7] J. Braun, C. Beaumont, Styles of continental rifting: results from dynamic models of lithospheric extension, Canadian Society of Petroleum Geologists Memoir 12 (1987) pp. 241-258.

[8] J. Braun, Recent advances in quantitative modelling of compressional orogens, Encyclopedia of Life Support Systems, Unesco Publication (2003).

[9] M. Burkhard, The Helvetian of the western border of the Aar massif: tectonic evolution and metamorphism, Eclogae Geologicae Helvetiae 81 (1988) pp. 63-114.

[10] B. Burchfiel, Eastern european alpine system and the carpathian orocline as an example of collision tectonics, Tectonophysics 63 (1980) pp. 31-61.

[11] J.P. Burg, T.V. Gerya, The role of viscous heating in Barrovian metamorphism of collisional orogens : thermomechanical models and application to the Lepontine Dome in the Central Alps, Journal of Metamorphic Geology, 23(2) (2005) pp. 75-95.

[12] T Burri, A Berger, M Engi, Tertiary migmatites in the Central Alps: Regional distribution, field relations, conditions of formation, and tectonic implications, Schweiz. Min. und Petro. Mitt., 85 (2005) pp. $215-232$.

[13] Byerlee, J.D., Friction of rocks, Pure and Applied Geophysics, 116 (1978) pp. 615-626.

[14] N. Challandes, D. Marquer, I. Villa, Dating the evolution of C - S microstructures : a combined 39Ar / 40Ar step-heating and UV laserprobe analysis of the Alpine Roffna shear zone, Chemical Geology 197 (1-4) (2003) pp. $3-19$.

[15] N. Challandes, D. Marquer, I.M. Villa, PTt modelling, fluid circulation, and 39Ar / 40Ar and Rb-Sr mica ages in the Aar Massif shear zones (Swiss Alps). Swiss J. Geosci. (2008).

[16] L. Ciancaleoni, D. Marquer, Late Oligocene to early Miocene extrusion at the eastern border of the Lepontine dome of the central Alps (Bergell and Insubric areas, eastern central Alps). Tectonics, 27(4) (2008) TC4008

[17] J. Dale, J. Holland, Geothermobarometry, P-T paths and metamorphic field gradient of high-pressure rocks from the Adula Nappe, Central Alps., Journal of Metamorphic Geology 21 (2003) pp. 813-829.

[18] J. Dercourt, M. Gaetani, B. Vrielync, E. Barrier, M. Biju-Duval, B. ans Brunet, J. Cadet, S. Crasquin, M. Sandulescu, Atlas peri-tethys - palaeogeographical maps, CCGM/CGMW Paris (2000).

[19] M. Engi, R. Bousquet, A. Berger, Metamorphic structure of the alps: Central alps, Mitt. Osterr. Miner. Ges. 149 (2004) pp. 157-173.

[20] P. England, C. Wilkins, A simple analytical approximation to the temperature structure in subduction zones, Geophysic J. Int. 159 (200) pp. 1138-1154.

[21] A. Escher, C. Beaumont, Formation, burial and exhumation of basement nappes at crustal scale : a geometric model based on the western Swiss-Italian Alps, Journal of Structural Geology 19 (7) (1997) pp. 955-974.

[22] T.V. Gerya, B. Stockhert, A. Perchuk, Exhumation of high-pressure metamorphic rocks in a subduction channel: A numerical simulation, Tectonics 21 (6) (2006) pp. 1056.

[23] T.V. Gerya, B. Stockhert, Two-dimensional numerical modeling of tectonic and metamorphic histories at active continental margins, Int. J. Earth. Sci. (Geol. Rundsch) 95 (2006) pp. 250-274 
[24] P. Gillet, P. Choukroune, M. Ballevre, P. Davy, Thickening history of the western alps, Earth and Planetary Science Letter 78 (1986) pp. 44-52.

[25] T.P. Gladczenko, K. Hinz, O. Eldholm, H. Meyer, S. Neben, J. Skogseid, South-Atlantic volcanic margins, Journal of the Geological Society of London 154 (1997) pp. 465-470.

[26] B. Goffe, R. Bousquet, P. Henry, X. Le Pichon, Effect of the chemical composition of the crust on the metamorphic evolution of orogenic wedges, Journal of Metamorphic Geology 21 (2003) pp. 123-141.

[27] B. Goffe, S. Schwartz, J. Lardeaux, Bousquet, Metamorphic structure of the alps: Western and ligurian alps, Mitt. Osterr. Miner. Ges. 149 (2004) pp. 125-144.

[28] F. Gueydan, Y.M. Leroy, L.Jolivet, Mechanics of low-angle extensional shearzones at the brittle-ductile transition, Journal of Geophysical Research, 109 (2004) B12407.

[29] S. Guillot, E. Garzanti, D. Baratoux, D. Marquer, G. Maheo, J. de Sigoyer. Reconstructing the total shortening history of the NW Himalaya, Geochemestry Geophysics Geosystems 4(7) (2003) pp. 1064.

[30] B. Hacker, G. Abers, S. Peacock, Subduction factory 1. Theoretical mineralogy, densites, seismic wave speeds and $\mathrm{H} 2 \mathrm{O}$ contents, journal of Geophysical Research 108 (B1) (2003) pp. 10.1-10.26.

[31] B. Hacker, S. Peacock, G. Abers, S. Holloway, Subduction factory 2.Are intermediate-depth earthquakes in subduction slabs linked to metamorphic dehydration reactions?, Journal of Geophysical Research 108 (B1) (2003) pp. 11.1-11.16.

[32] J. Jackson, Faulting, Flow, and the Strength of the Continental Lithosphere, International Geology Review 44(1) (2002) pp. 39-61.

[33] J. Jackson, Strength of the continental lithosphere: Time to abandon the jelly sandwich?, GSA Today 12(9) (2002) pp. 4-10.

[34] H. Jenny, G. Frischknecht, J. Kopp, Geologie der adula., Ph.D. thesis, Beitrage zur geologischen Karte der Schweiz - NF 51 (1923).

[35] L. Jolivet, H. Raimbourg, L. Labrousse, D. Avigad, Y. Leroy, H. Austrheim, T. Andersen, Softening trigerred by eclogitization, the first step toward exhumation during continental subduction, Earth and Planetary Science Letter 237 (2005) pp. 532-547.

[36] S.-I. Karato, P. Wu, Rheology of the upper mantle: A synthesis., Science 260 (1993) pp. 771-778.

[37] P. Leloup, N. Arnaud, E. Sobel, R. Lacassin, Alpine thermal and structural evolution of the highest external crystalline massif: The mont blanc, Tectonics 24 (2005) TC4002.

[38] M. Leroy, F. Gueydan, O. Dauteuil, Uplift and strength evolution of passive margins inferred from 2D conductive modeling, 172 (2008) pp. 464-476.

[39] S. Low, Die tektono-metamorphe entwicklung der nordlichen adula-decke (zentralalpen, schweiz)., Ph.D. thesis, Beitrage zur geologischen Karte der Schweiz - NF 161 (1987).

[40] J. Malavieille, Modelisation experimentale des chevauchements imbriques: application aux chaines de montagnes, Bulletin de la Societe geologique de France 26(1) (1984) pp. 129-138.

[41] D. Marquer, Structures et cinematique des deformations alpines dans le granite de Truzzo (nappe de tambo: Alpes centrales suisses), Eclogae Geologicae Helvetiae 84(1) (1991) pp. 107-123.

[42] D. Marquer, N. Challandes, T. Baudin, Shear zone patterns and strain distribution at the scale of a Penninic nappe: the Suretta nappe (Eastern Swiss Alps), Journal of Structural Geology 18(6) (1996) 753-764.

[43] M. Mattauer, Intracrustal subduction, crust-mantle decollement and crustal-stacking wedge in the himalayas and other collision belts, Geol. Soc. London Collision Tectonics - Vol Spec 19 (1986) pp. 37-50.

[44] M. Maxelon, N. Mancktelow, Three-dimensional geometry ant tectonostratigraphy of the Pennine zone, Central Alps, Switzerland and Nothern Italy, Earth-Sciences Reviews 71 (2005) pp. 171-227.

[45] C. Meyre, A. Puschnig, High-pressure metamorphism and deformation at trescolmen, adula nappe, central alps., Schweiz. Min. und Petro. Mitt. 73 (1993) pp. 277-283. 
[46] C. Meyre, High-Pressure metamorphism and deformation of the middle Adula nappe (Cental Alps, Switzerland)., Ph.D. thesis, Basel (1998).

[47] C. Meyre, C. De Capitani, T. Zack, M. Frey, Petrology of High-Pressure metapelites from the Adula nappe (Central Alps, Switzerland), Journal of Petrology 40 (1) (1999) pp. 199-213.

[48] W.U. Mohriak, J.F. Dewey, Deep seismic reflectors in the Campos basin, offshore Brazil, Geophysical Journal of the Royal Astronomical Society 89(1) (1987) pp. 133-140.

[49] A. Nairn, L. Ricou, B. Vrielync, J. Dercourt, The ocean basins and margins - vol 8: The tethys ocean, Plenium Publishing Crop. (1988) 530p.

[50] M. Paterson, F. Luan, Quartzite rheology under geological conditions, Geologial Society Special Publication 54 (1990) pp. 299-307.

[51] S.A. Peacock, Fluid Processes in Subduction Zones, Science 248(4953) (1990) pp. 329-337.

[52] S. Peacock, Thermal and Petrologic Structure of Subduction Zones, Geophysical Monograph (1996) pp. 119133.

[53] M. Pfifner, V. Trommsdorff, The high-pressure ultra-mafic-carbonate suite of Cima Lunga-Adula, Central Alps: Excursions to Cima di Gagnone and Alpe Arami., Schweizerische Mineralogische und Petrolographische Mitteilungen 78 (1998) pp. 337-354.

[54] O. Pfiffner, S. Ellis, C. Beaumont, Collision tectonics in the Swiss Alps : Insight from geodynamic modeling, Tectonics 19 (6) (2000) pp. 1065-1094.

[55] G. Ranalli, Z.-M. Yin, Critical stress difference and orientation of faults in rocks with strength anisotropies: the two-dimensional case, Journal of Structural Geology 12 (1990) pp. 1067-1071.

[56] G. Ranalli, Rheology of the crust and its role in tectonic reactivation, Journal of Geodynamic 30 (2000) pp. $3-15$.

[57] G. Rosenbaum, G. Lister, Formation of arcuate orogenic belts in the western Mediterranean region, Geological Society of America - Special Paper 383 (2004) pp. 41-56.

[58] S. Schmid, O. Pfifner, N. Froitzheim, G. Schonborn, Geophysical-geological transect and tectonic evolution of the swiss-italian alps., Tectonics 15 (1996) pp. 1036-1064.

[59] S. Schmid, O. Pfiffner, G. Schonborn, N. Froitzheim, E. Kissling, Integrated cross section and tectonic evolution of the alps along the eastern traverse, Pfiffner et al. (Eds.): Deep structure of the Swiss Alps Results of NRP20, Basel (1997) pp. 289-304.

[60] S. Schmid, O. Pfiffner, G. Schreurs, Rifting and collision in the penninic zone of eastern switzerland, Pfiffner et al. (Eds.): Deep structure of the Swiss Alps Results of NRP20, Basel (1997) pp. 60-185.

[61] S. Schmid, B. Fugenschuh, B. Kissling, R. Schuster, Tectonic map and overall architecture of the Alpine orogen, Eclogae - Swiss journal of Geosciences 97 (1) (2004) pp. 93-117.

[62] G. Stampfli, J. Mosar, D. Marquer, R. Marchand, T. Baudin, G. Borel, Subduction and obduction processes in the Swiss Alps, Tectonophysics 296 (1998) pp. 159-204.

[63] D.S. Sawyer, Brittle failure in the upper mantle during extension of continental lithosphere. J. Geophys. Res. 90 (1985), pp. 30213125.

[64] D. Turcotte, G. Schubert, Geodynamics application of continuum physics to geological problems, John Wiley and Sons (1982).

[65] K. R. Wilks, N. L. Carter, Rheology of some continental lower crustal rocks, Tectonophysics 182 (1990) pp. $57-77$. 